\title{
Main Root Adaptations in Pepper Germplasm (Capsicum spp.) to Phosphorus Low-Input Conditions
}

\author{
Leandro Pereira-Dias ${ }^{1}{ }^{(D}$, Daniel Gil-Villar ${ }^{1}{ }^{(\mathbb{D}}$, Vincente Castell-Zeising ${ }^{2}$, Ana Quiñones ${ }^{3}{ }^{(\mathbb{C}}$, \\ Ángeles Calatayud ${ }^{3}$, Adrián Rodríguez-Burruezo ${ }^{1}$ and Ana Fita ${ }^{1, *(\mathbb{C})}$ \\ 1 Instituto de Conservación y Mejora de la Agrodiversidad Valenciana (COMAV), \\ Universitat Politècnica de València, 46022 Valencia, Spain; leapedia@etsiamn.upv.es (L.P.-D.); \\ dagivil@upv.es (D.G.-V.); adrodbur@upv.es (A.R.-B.) \\ 2 Departamento de Producción Vegetal, Universitat Politècnica de València, 46022 Valencia, Spain; \\ vcastell@prv.upv.es \\ 3 Instituto Valenciano de Investigaciones Agrarias (IVIA), 46113 Moncada, Valencia, Spain; \\ quinones_ana@gva.es (A.Q.); calatayud_ang@gva.es (Á.C.) \\ * Correspondence: anfifer@btc.upv.es; Tel.: +34-963-879-418
}

Received: 27 March 2020; Accepted: 19 April 2020; Published: 1 May 2020

\begin{abstract}
Agriculture will face many challenges regarding food security and sustainability. Improving phosphorus use efficiency is of paramount importance to face the needs of a growing population while decreasing the toll on the environment. Pepper (Capsicum spp.) is widely cultivated around the world; hence, any breakthrough in this field would have a major impact in agricultural systems. Herein, the response to phosphorus low-input conditions is reported for 25 pepper accessions regarding phosphorus use efficiency, biomass and root traits. Results suggest a differential response from different plant organs to phosphorus starvation. Roots presented the lowest phosphorus levels, possibly due to mobilizations towards above-ground organs. Accessions showed a wide range of variability regarding efficiency parameters, offering the possibility of selecting materials for different inputs. Accessions bol_144 and fra_DLL showed an interesting phosphorus efficiency ratio under low-input conditions, whereas mex_scm and sp_piq showed high phosphorus uptake efficiency and mex_pas and sp_bola the highest values for phosphorus use efficiency. Phosphorus low-input conditions favored root instead of aerial growth, enabling increases of root total length, proportion of root length dedicated to fine roots and root specific length while decreasing roots' average diameter. Positive correlation was found between fine roots and phosphorus efficiency parameters, reinforcing the importance of this adaptation to biomass yield under low-input conditions. This work provides relevant first insights into pepper's response to phosphorus low-input conditions.
\end{abstract}

Keywords: Capsicum annuum; root structure; root hairs; phosphorus use efficiency; P-starvation; abiotic stress; macrominerals; nutrient; breeding

\section{Introduction}

Agriculture will face many challenges in the next generations, especially those related to food security and agricultural sustainability $[1,2]$. On one hand, intensive agriculture has a significant impact on the environment, contributing to soil erosion, soil salinization, eutrophication and contamination of water bodies, and biodiversity reduction $[3,4]$. On the other hand, agricultural systems need to be improved in order to cope with requirements of an increasing population as well as the impact of climate change consequences $[1,5]$.

In both cases, one of the most critical resources involved is phosphorus $(\mathrm{P})$, an inorganic mineral with a major role within the physiochemical processes of plants [6,7]. Since almost $40 \%$ of the world's 
arable land lacks of $\mathrm{P}$ or the soil properties to make it available for crops, $\mathrm{P}$ absence is a major constraint to food production all around the world [8-10]. Until now, application of P-enriched fertilizers has been the main strategy to face its deficiency in soils despite the severe contaminants emissions associated to its production $[3,9,11]$. In addition, only 15 to $40 \%$ of the added $P$ is taken up by crops $[3,9,12]$, while the remaining ends up being washed down through the soil, contributing to eutrophication of water bodies $[13,14]$. Furthermore, as costs of extraction increase and rock-phosphate reserves decline, $\mathrm{P}$ is becoming an extremely expensive resource that is already unaffordable in many regions of the globe [10]. As demand for P-enriched fertilizers is going to increase in the next decades, the control for P supply will be a source of conflicts [7,9]. Therefore, there is a need for P low-input adapted varieties.

The response to P-starvation conditions has been studied for a few model organisms and some economically important crops, such as soybean, maize, sunflower, brassica or melon over the last decades [15-19]. As a result, researchers have linked several root traits to a greater performance under low P conditions [20]. Thus, morphological changes, such as the increment of number of root hairs and higher root branching $[15,18,21]$, as well as physiological changes, such as cellular structure alteration, enhanced phosphatases enzyme activity and organic acids production and root $P$ transporters enhanced expression $[12,16,22,23]$, are adaptations expressed under P-starvation conditions. The exploitation of these plant adaptations could have a remarkable impact on the reduction of chemical fertilizers inputs in agricultural systems $[12,24]$.

Peppers (Capsicum spp.) are one of the most relevant vegetables, grown in almost all temperate and tropical regions of the world [25]. Food and Agriculture Organization of the United Nations (FAO) last available data estimates around $40 \times 10^{6} \mathrm{t}$ of pepper produced each year [26]. Therefore, improving pepper for its uptake and use of $\mathrm{P}$ would significantly reduce the need for P-fertilizer applications [3,12]. Notwithstanding, the development of improved Capsicum varieties for P low-input conditions is a challenging goal and is conditioned by both the availability of genetic variability within Capsicum and the understanding of the mechanisms underlying the response. Regarding the first point, Capsicum spp., particularly Capsicum annuum L., is remarkably diverse, as well as adapted to a wide range of environments and, therefore, tolerant to several abiotic stresses [27-30]. However, pepper fundamentals regarding this subject have never been studied. Hence, we believe that an exhaustive characterization of pepper germplasm for its responses under $\mathrm{P}$ low-input conditions is of paramount importance in order to recognize the variability within the genus, to enhance our understanding regarding the responses activated under such conditions and, finally, to link those responses to the genomic regions controlling them. Herein, the characterization of the main root adaptations of pepper accessions to low $\mathrm{P}$ conditions was established as a main goal, as a first step towards the identification of elite individuals for future pepper breeding programs.

\section{Materials and Methods}

\subsection{Germplasm}

A collection of 25 pepper accessions, encompassing 22 Capsicum annuum, two Capsicum chinense and one Capsicum frutescens accessions, comprising a wide range of variability for fruit shape, fruit pungency, fruit color, biotic resistances and adaptation to the environments, was studied herein [31] (Table 1). The considered collection belongs to the Instituto Universitario de Conservación y Mejora de la Agrodiversidad Valenciana (COMAV) Germplasm Bank (Universitat Politècnica de València, Spain) and to the COMAV Capsicum breeding group, and was selected based on previous experiments, where an interesting performance and diversity for several relevant root and $\mathrm{P}$ uptake traits was observed [32]. 
Table 1. List of the 25 accessions and corresponding abbreviation, species, varietal status, origin, fruit shape, fruit taste, fruit color and trial year.

\begin{tabular}{|c|c|c|c|c|c|c|c|}
\hline Abbreviation & Species & Accession (UPV Genebank Code) & Origin & Fruit Shape & $\begin{array}{l}\text { Fruit } \\
\text { Taste }\end{array}$ & $\begin{array}{l}\text { Fruit } \\
\text { Color }\end{array}$ & Trial \\
\hline & $\begin{array}{c}\text { Traditional } \\
\text { varieties }\end{array}$ & & & & & & \\
\hline fra_DLL & Capsicum annuит & Doux Long des Landes & France (INRA-GEVES, F. Jourdan) & Cayenne, long-sized & Sweet & Red & Trial 2 \\
\hline mex $096 \mathrm{D}$ & Capsicum аппичт & Chile Ancho Poblano & Mexico, Aguascalientes & Triangular, Pochard's C4 type & Hot & Red & Trial 2 \\
\hline mex_103B & Capsicum annuиm & Chile Ancho Poblano & Mexico, Aguascalientes & Triangular, Pochard's C4 type & Hot & Red & Trial 2 \\
\hline mex_pas & Capsicum аппиит & Pasilla Bajío & Mexico, Reymer Seeds & Cayenne, long-sized & Hot & Brown & Trial 1 and Trial 2 \\
\hline mex_ng & Capsicum annuиm & Numex Garnet & Mexico, Aguascalientes & Elongated, Pochard's C2 type & Sweet & Red & Trial 2 \\
\hline mu_esp & Capsicum aпnuит & Jalapeno Espinalteco & Mexico/USA (P. W. Bosland) & Jalapeno & Hot & Red & Trial 1 and Trial 2 \\
\hline sp_060 & Capsicum annuиm & $\begin{array}{l}\text { Pimiento morrón de bola } \\
\text { (BGV00060) }\end{array}$ & Spain, Zamora & Round, Pochard's F type & Sweet & Red & Trial 2 \\
\hline sp_11814 & Capsicum annuит & Dulce Italiano (BGV11814) & Spain, León & Elongated, Pochard's C2 type & Sweet & Red & Trial 2 \\
\hline sp_bola & Capsicum anпuит & Pimiento de bola, ñora & $\begin{array}{c}\text { Spain, Murcia (P.D.O. Pimentón } \\
\text { Murcia) }\end{array}$ & Round, Pochard's N type & Sweet & Red & Trial 1 and Trial 2 \\
\hline sp_lam & Capsicum annuит & Lamuyo & Spain, Valencia & Blocky, Pochard's B1 or B2 type & Sweet & Red & Trial 2 \\
\hline sp_piq & Capsicum annuиm & Pimiento Piquillo de Lodosa & $\begin{array}{c}\text { Spain, Navarra (P.D.O. Piquillo } \\
\text { Lodosa) }\end{array}$ & Triangular, Pochard's C4 type & Sweet & Red & Trial 1 and Trial 2 \\
\hline usa_chi & Capsicum annuиm & Chimayó & USA, New Mexico (P. W. Bosland) & Blocky small-sized, Pochard's B4 type & Hot & Red & Trial 1 \\
\hline usa_cong & Capsicum annuит & Numex Conquistador & USA, New Mexico & Elongated, Pochard's C2 type & Sweet & Red & Trial 2 \\
\hline usa_jap & Capsicum annuиm & Chile Japonés & USA, New Mexico & Cayenne, very short-sized & Hot & Red & Trial 2 \\
\hline usa_numex & Capsicum апnиит & Numex X & USA, New Mexico & Elongated, Pochard's C2 type & Hot & Red & Trial 2 \\
\hline \multirow[t]{2}{*}{ usa_sandia } & Capsicum annuит & Numex Sandia (BGV13293) & USA, New Mexico & Elongated, Pochard's C2 type & Hot & Red & Trial 2 \\
\hline & Experimental lines & & & & & & \\
\hline mex_scm & Capsicum annuиm & $\begin{array}{l}\text { Serrano Criollo de Morellos } \\
\text { (SCM334) }\end{array}$ & Mexico & Serrano & Hot & Red & Trial 1 and Trial 2 \\
\hline \multirow[t]{2}{*}{ sp_cwr } & Capsicum annuum & California Wonder & Spain, Valencia (COMAV) & Blocky, Pochard's A type & Sweet & Red & Trial 1 \\
\hline & $\begin{array}{l}\text { Commercial } \\
\text { hybrids }\left(F_{1}\right)\end{array}$ & & & & & & \\
\hline $\mathrm{sp}$ anc & Capsicum anпuит & Ancares & Spain (Ramiro Arnedo) & Blocky, Pochard's B1 or B2 type & Sweet & Red & Trial 2 \\
\hline sp_cat & Capsicum апnиит & Catedral & Spain (Zeraim Ibérica) & Blocky, Pochard's A type & Sweet & Red & Trial 1 \\
\hline sp_lobo & Capsicum anпuит & El Lobo & Spain (Zeraim Ibérica) & Blocky, Pochard's A type & Sweet & Red & Trial 2 \\
\hline \multirow[t]{2}{*}{ sp_mel } & Capsicum anпuит & Melchor & Spain (Ramiro Arnedo) & Blocky, Pochard's A type & Sweet & Red & Trial 1 \\
\hline & Other Capsicums & & & & & & \\
\hline bol_037 & Capsicum chinense & Bol-37R (BGV007644) & Chuquisaca, Bolivia & Triangular, small-sized, thin flesh & Hot & Red & Trial 1 \\
\hline bol_144 & Capsicum baccatum & Bol-144 (BGV007751) & Bolivia, Santa Cruz & Cayenne, very short-sized & Hot & Red & Trial 1 \\
\hline eq_973 & Capsicum chinense & ECU-973 & Ecuador, Napo & Triangular, small-sized, thin flesh & Hot & Red & Trial 1 \\
\hline
\end{tabular}




\subsection{Germination and Cultivation Conditions}

Seeds were surface sterilized with a $30 \% \mathrm{NaClO}$ solution (v:v) for five minutes, followed by rinsing with steril deionized water, and transfered to individual Petri dishes containing a wet layer of cotton under a filter paper disk. Two drops of $2 \%$ Tetramethylthiuram disulphide solution were added to each Petri dish to prevent fungal proliferation. Petri dishes were kept under germination chamber conditions until two-cotyledon stage. Seedlings were then transferred to seedling trays filled with Neuhaus N3 substrate (Klasmann-Dellmann GmbH, Geeste, Germany), kept under heated nursery conditions until the five leaves stage and, finally, transplanted to the greenhouse.

The experiment was carried out in two years. In the first year (from now on Trial 1), 12 accessions were trialed and the five most interesting genotypes were re-trialed in the second year (from now on Trial 2), against 13 new accessions (Table 1). In both trial years, plants were grown for 60 days under a mesh greenhouse, during the spring-summer cycle, on COMAV experimental fields (Universitat Politècnica de València Vera Campus GPS coordinates: $39^{\circ} 28^{\prime} 56.33^{\prime \prime} \mathrm{N} ; 0^{\circ} 20^{\prime} 10.88^{\prime \prime} \mathrm{W}$ ). Transplant was carried out in June and the experiment was finished in August. Nine (Trial 1) and six (Trial 2) plants, per accession and treatment, were grown in $15 \mathrm{~L}$ plastic pots filled with substrate made by mixing a part of soil with a part of sand (1:1) and arranged into a completely randomized design with six rows. Pots were spaced $1.2 \mathrm{~m}$ between rows and $0.40 \mathrm{~m}$ inside rows, while a drip irrigation system provided water and nutrient solutions to cover the plants' water and nutritional requirements. Individual plants were trained with vertical strings, according to standard local practices for pepper. Plants were not pruned during the experiment in order to avoid interference with biomass yield. Likewise, phytosanitary treatments against whiteflies, spider mites, aphids and caterpillars were applied accordingly to population levels.

Plants were subjected to two treatments. On one hand, control treatment was applied using a standard solution providing all elements (Table S1). On the other hand, stress treatment (from now on $\mathrm{NoP}$ ) was applied using similar solution to the control treatment except for P carrying ions, which were removed from the formulation of the solution (Table S1).

\subsection{Sample Preparation}

After the 60 days period plants were harvested for processing. Shoot and fruits were processed separately in order to assess effects of $\mathrm{P}$ deprivation on both tissues. Each tissue was put into individual paper bags and dried at $70{ }^{\circ} \mathrm{C}$, until constant weight was achieved, in a Raypa ID-150 oven (R. Espinar S.L., Barcelona, Spain). At this point, shoot (SW, g) and fruit (FW, g) dry weights were determined, and those tissues were ground into a thin powder, using a domestic Taurus coffee grinder (Taurus Group, Oliana, Spain), for later mineral content analysis. Furthermore, all plants' roots were separated from substrate by gently washing them with running tap water and processed separately from other tissues [33]. This was done by hand, one root at a time (Figure 1).

For Trial $1(n=9)$, root hairs $(\varnothing<0.5 \mathrm{~mm})$ were separated from lateral roots $(\varnothing>0.5 \mathrm{~mm})$ and dried at $70{ }^{\circ} \mathrm{C}$ in order to obtain root hairs dry weight (RHW, g) (Figure 1). It is important to note that what is referred here as root hairs does not correctly translate to the root anatomical definition of root hairs; instead, it includes root hairs and some fine tertiary and lower order roots. However, herein it is useful to differentiate between the evaluated root parts. In the same way, lateral roots are mainly secondary roots; however, as can be seen in the picture Figure $1 \mathrm{C}$, they can also include a portion of tertiary roots, as it was impossible to separate all in such a large amount of samples. Lateral roots were scanned, using an Epson Expression 1640XL G650C scanner (Seiko Epson Corp., Suwa, Japan), and resulting images were analyzed by WinRIZHO ${ }^{\mathrm{TM}}$ Pro 2.3 software (Regent Instruments Inc., Québec, QC, Canada). Lateral root total length (LRL, $\mathrm{m}$ ), lateral root average diameter (LRAD, $\mathrm{mm}$ ) and total length of lateral roots with diameter under $\left(\mathrm{LRL}_{<1 \mathrm{~mm}}, \mathrm{~m}\right)$ and above $\left(\mathrm{LRL}_{>1 \mathrm{~mm}}, \mathrm{~m}\right) 1 \mathrm{~mm}$ were determined based on said images for each plant included in the experiment. Finally, scanned lateral roots were dried in order to obtain lateral roots dry weight (LRW, g) and ground for mineral content determination (Figure 1). From those measurements, several parameters were calculated 
in order to better characterize plants' performance. Hence, for trial 1, total root dry weight (RW, g) was determined as the sum of RHW and LRW and, therefore, total biomass dry weight (BW, g) was calculated as the sum of RW, SW and FW. In addition, root to shoot weight ratio (R/S) was calculated by dividing RW by SW; the percentage of root dry weight devoted to root hairs (RHW\%) was calculated by the division of RHW by RW. Furthermore, the proportion of root length devoted to fine lateral roots (PLFR, \%) was defined as the ratio between $\mathrm{LRL}_{<1 \mathrm{~mm}}$ and LRL. Finally, lateral root specific length (LRSL, m/g) was calculated by dividing LRL by LRW.

For Trial $2(n=6)$, roots were entirely scanned (Figure 1$)$. In order to fully capture a root's morphometrics, individual roots were properly spread over several transparent acetate sheets (Figure 1) and analyzed by WinRIZHO ${ }^{\mathrm{TM}}$ Pro 2.3 software (Regent Instruments Inc., Canada). Root total length $(\mathrm{RTL}, \mathrm{m})$, total root average diameter (TAD, $\mathrm{mm}$ ) and total length of roots with diameters under $\left(\mathrm{RL}_{<1 \mathrm{~mm}}, \mathrm{~m}\right)$ and above $\left(\mathrm{RL}_{>1 \mathrm{~mm}}, \mathrm{~m}\right) 1 \mathrm{~mm}$, were determined for each plant. Finally, the scanned roots were dried until constant weight was achieved and ground to a powder as in Trial 1. Root hairs dry weight (RHW, g), lateral roots dry weight (LRW, g), total root dry weight (RW, g), total biomass dry weight $(B W, g)$, root to shoot ratio $(\mathrm{R} / \mathrm{S})$, percentage of root dry weight devoted to root hairs (RHW\%) and root specific length (RSL, m/g) were determined as in Trial 1. Finally, the proportion of root length devoted to fine lateral roots was determined, that is, including root hairs and roots below $1 \mathrm{~mm}$ (PFR, $\%$ ), as the ratio between $\mathrm{RL}_{<1 \mathrm{~mm}}$ and $\mathrm{RTL}$.

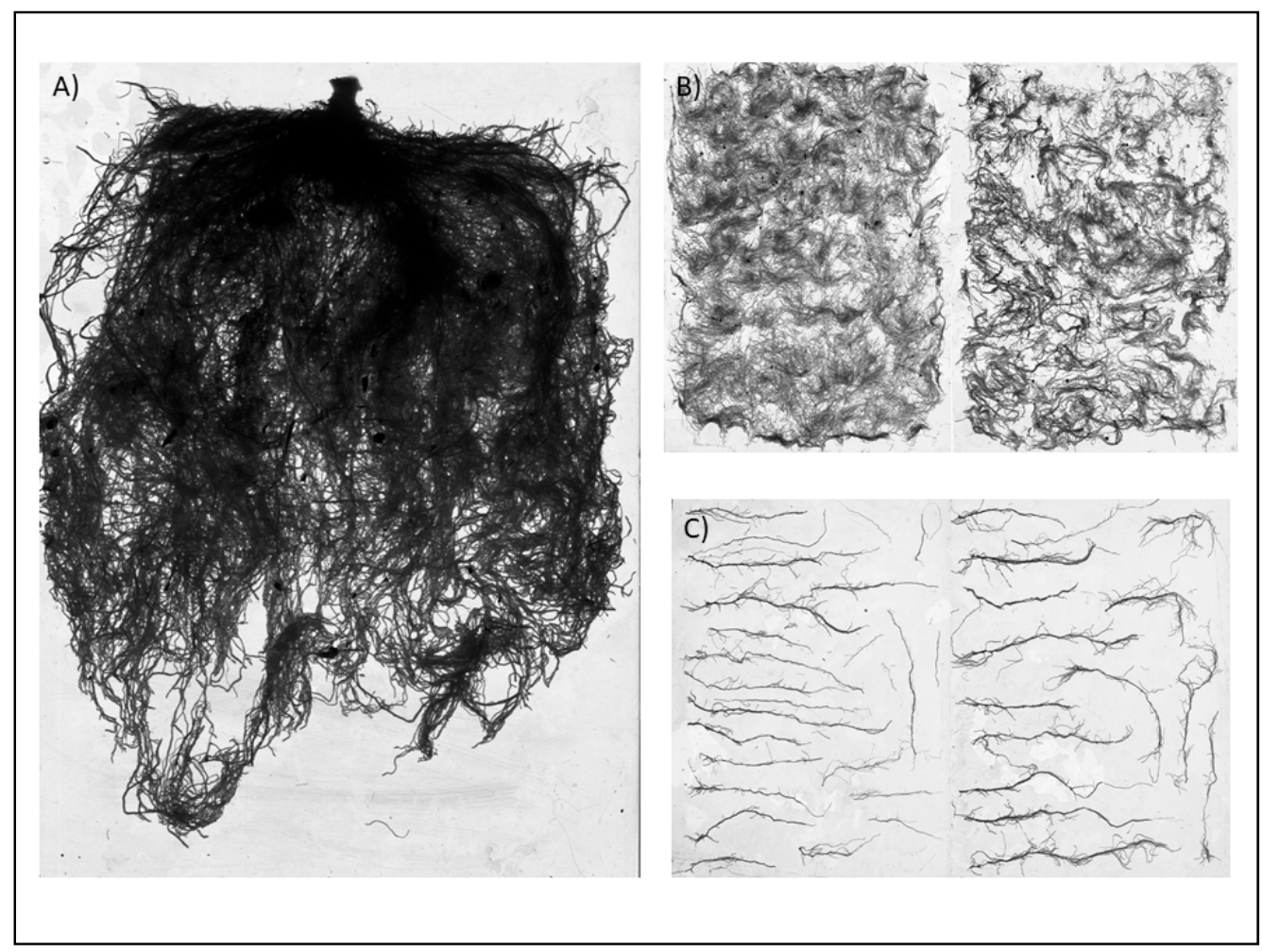

Figure 1. Illustration of the roots along the scanning process (from a representative sample). Individual root systems were separated from the soil with running tap water and taken to the laboratory to be scanned and dried. In Trial 1, whole roots (A) were separated into (B) root hairs $(\varnothing<0.5 \mathrm{~mm})$ and (C) lateral roots $(\varnothing>0.5 \mathrm{~mm})$. Root hairs $(B)$ were only weighed while lateral roots $(\mathbf{C})$ were scanned and weighed. In Trial 2, whole roots (A) were also separated into root hairs (B) and lateral roots (C) and both were scanned and weighed.

\subsection{Tissue Mineral Concentration Assessment}

Before mineral content determination, samples were mineralized [34]. Thus, $2 \mathrm{~g}$ of powdered plant tissue were calcined for $2 \mathrm{~h}$ in a muffle at $450{ }^{\circ} \mathrm{C}$. Ashes resulting from mineralization were let to 
cool down, weighted and then hydrated with $2 \mathrm{~mL}$ of distilled water followed by addition of $2 \mathrm{~mL}$ of concentrated $\mathrm{HCl}$ (Scharlau, Valencia, Spain). At this point, the solution was heated on a hot plate, until first fumes appeared, and then filtered with Whatman filter paper (Sigma-Aldrich, St. Louis, MI, USA). Finally, distilled water was added in order to make up to $100 \mathrm{~mL}$ volume [34].

In Trial $1(n=4)$, phosphorus $(\mathrm{P})$, potassium $(\mathrm{K})$, calcium $(\mathrm{Ca})$, magnesium $(\mathrm{Mg})$, sodium $(\mathrm{Na})$ and sulfur (S) concentration (g $100 \mathrm{~g}^{-1} \mathrm{DW}$ ) in different plant tissues (root, shoot and fruits, [Mineral $]_{\text {Tissue }}$ ) was determined by Inductively Coupled Plasma-Atomic Emission Spectrometry (ICP-AES; iCAp-AES 6000, Thermo Scientific, Cambridge UK). Samples were digested for $24 \mathrm{~h}$ by adding $10 \mathrm{~mL} 65 \% \mathrm{HNO}_{3}$ solution (Panreac Quimica S.A.U., Barcelona, Spain) to $0.5 \mathrm{~g}$ dried material, in a $25 \mathrm{~mL}$ open vessel. Digested samples were then boiled at $120^{\circ} \mathrm{C}$ for $10 \mathrm{~min}$ followed by another $25 \mathrm{~min}$ at $170{ }^{\circ} \mathrm{C}$. Finally, samples were cooled, $2 \mathrm{~mL}$ of $70 \% \mathrm{HClO}_{4}$ was added (Panreac Quimica S.A.U., Barcelona, Spain) and were then heated at $200{ }^{\circ} \mathrm{C}$ for $40 \mathrm{~min}$. At this point, samples were transferred to a flask and volume was brought up to $25 \mathrm{~mL}$ with distilled water.

For Trial $2(n=6)$, leaves' P-concentration ( $\left.[\mathrm{P}]_{\text {Shoot }}\right)$ was determined by colorimetric reaction (MAPA, 1994). This method is based on absorbance measurement at $430 \mathrm{~nm}$ of each sample in acid solution and on the presence of vanadium $\left(\mathrm{V}^{5+}\right)$ and molybdenum $\left(\mathrm{Mo}^{6+}\right)$ ions. Under these conditions, phosphoric acid forms a phosphomolybvanadate complex that gives yellow coloration. Hence, $5 \mathrm{~mL}$ of mineralized solution were pipetted into a new $25 \mathrm{~mL}$ volumetric flask, followed by the addition of $5 \mathrm{~mL}$ of nitro-vanado-molybdic reagent. Volume was then brought up to $25 \mathrm{~mL}$ with distilled water. Prior to mineral concentration determination, a standard curve was constructed with standards $0,2,4,6,8,10$ and $12 \mu \mathrm{g}$ of $\mathrm{P} \mathrm{mL}^{-1}$ prepared from an initial solution of $20 \mu \mathrm{g}$ of $\mathrm{P} \mathrm{mL}{ }^{-1}$. Sample P concentration was determined using a 6305 model UV/V spectrophotometer (Jenway, Gransmore Green, England, UK) at $430 \mathrm{~nm}$ against a standard curve.

\subsection{Phosphorus Uptake and Use Efficiency Parameters}

In order to better characterize treatment effect on accessions performance, several widely-used $P$ uptake and P use efficiency parameters (PUE) were calculated based on previous works $[18,21]$ (Table 2).

Table 2. P uptake and P use efficiency (PUE) parameters used in this experiment and corresponding abbreviation, formula and expressed units. Dry weight (DW), total biomass dry weight biomass weight (BW).

\begin{tabular}{|c|c|c|c|}
\hline Parameter & Abbreviation & Formula $^{1}$ & Units \\
\hline Tissue total P content & $\begin{array}{c}\text { RootP, ShootP, } \\
\text { FruitP }\end{array}$ & {$[\mathrm{P}]_{\text {Tissue }} \times \mathrm{DW}_{\text {Tissue }}$} & G \\
\hline Plant total P content & $\mathrm{PTP}^{2}$ & $\begin{array}{c}{[\mathrm{P}]_{\text {Root }} \times \mathrm{DW}_{\text {Root }}+[\mathrm{P}]_{\text {Shoot }} \times \mathrm{DW}_{\text {Shoot }}+} \\
{[\mathrm{P}]_{\text {Fruit }} \times \mathrm{DW}_{\text {Fruit }}}\end{array}$ & $\mathrm{mg} P$ \\
\hline P uptake efficiency & $\mathrm{PUpE}^{3}$ & $\left([\mathrm{P}]_{\text {Control }} \times \mathrm{BW}_{\text {Control }}\right)-\left([\mathrm{P}]_{\mathrm{NoP}} \times \mathrm{BW}_{\mathrm{NoP}}\right)$ & $\mathrm{mg} P$ \\
\hline P utilization efficiency & $P U t E^{3}$ & $\begin{array}{c}\left(\mathrm{BW}_{\text {Control }}-\mathrm{BW}_{\mathrm{NoP}}\right) /\left(\left([\mathrm{P}]_{\text {Control }} \times\right.\right. \\
\left.\left.\mathrm{BW}_{\text {Control }}\right)-\left([\mathrm{P}]_{\mathrm{NoP}} \times \mathrm{BW}_{\mathrm{NoP}}\right)\right)\end{array}$ & $\begin{array}{l}\mathrm{g} D W \\
\mathrm{~g}^{-1} \mathrm{P}\end{array}$ \\
\hline Physiological P use efficiency & PPUE & $\mathrm{BW}_{\text {Control }} /[\mathrm{P}]_{\text {Control }}$ and $\mathrm{BW}_{\mathrm{NoP}} /[\mathrm{P}]_{\mathrm{NoP}}$ & $\begin{array}{l}\mathrm{g}^{2} \mathrm{DW} \\
\mathrm{g}^{-1} \mathrm{P}\end{array}$ \\
\hline$P$ efficiency ratio & PER & $\begin{array}{c}\mathrm{BW}_{\text {Control }} /\left([\mathrm{P}]_{\text {Control }} \times \mathrm{BW}_{\text {Control }}\right) \text { and } \\
\mathrm{BW}_{\mathrm{NoP}} /\left([\mathrm{P}]_{\mathrm{NoP}} \times \mathrm{BW}_{\mathrm{NoP}}\right)\end{array}$ & $\begin{array}{l}\text { g DW } \\
\mathrm{g}^{-1} \mathrm{P}\end{array}$ \\
\hline
\end{tabular}

${ }^{1} \mathrm{P}$ concentration $([\mathrm{P}])$, Dry weight $(\mathrm{DW})$, total biomass dry weight $(\mathrm{BW})^{2}$ Note that for Trial 2 only $[\mathrm{P}]_{\text {shoot }}$ was measured, therefore PTP was obtained as $[\mathrm{P}]_{\text {shoot }} \times \mathrm{BW} ;{ }^{3}$ Note that $[\mathrm{P}]$ in Trial 1 is the weighted average $[\mathrm{P}]$ among different tissues, whereas in Trial $2[\mathrm{P}]=[\mathrm{P}]_{\text {shoot }}$.

\subsection{Statistical Analysis}

Two-way factorial analysis of variance (ANOVA) was performed using individual plant values in order to assess accession and treatment effects and interaction significance [35]. In addition, 
Student-Newman-Keuls post-hoc multiple range test $(p<0.05)$ was used to detect significant differences among accession means for all evaluated traits. Finally, trait differences between treatments $\left(\mu_{\text {NoP- }} \mu_{\text {Control }}\right)$ were used to perform multivariate Principal Component Analysis (PCA) using Euclidean pairwise distances. In addition, traits variation (\%) between control and NoP conditions was calculated as $\left(\frac{\mu_{\text {NoP }}-\mu_{\text {Control }}}{\mu_{\text {Control }}}\right) \times 100 \%$. All statistical analysis were performed using Statgraphics Centurion XVII (StatPoint Technologies, Warrenton, VA, USA) and plotted using R package ggplot2 [36,37].

\section{Results}

\subsection{General Treatment Effect on P and Other Minerals Concentrations for Trial 1}

$\mathrm{P}$ concentration $([\mathrm{P}])$ in plant tissues is an important indicator of both treatment effectiveness and accession's capability to make the most with the available resources. In Trial $1(n=4)$, plants cultivated under NoP conditions showed significantly lower [P] compared to control plants. This behavior was statistically significant for all three sampled tissues (Table S2). For $[\mathrm{P}]_{\text {Roots }}$, there was a reduction from

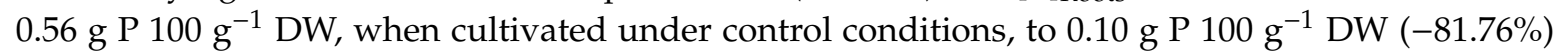

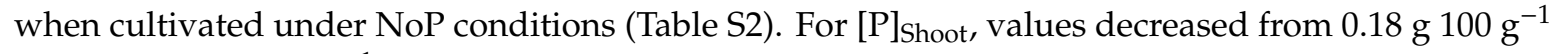

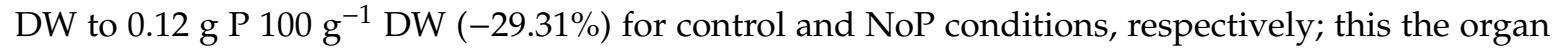
is less affected by the treatment (Table S2). Finally, fruit P levels dropped from $0.26 \mathrm{~g} \mathrm{P} 100 \mathrm{~g}^{-1} \mathrm{DW}$,

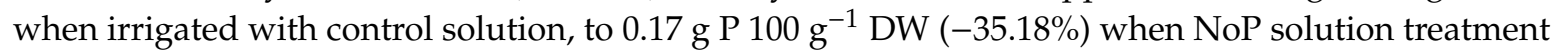
was applied (Table S2).

Concentration of other macrominerals was determined in order to assess possible deficiencies induced by the applied treatments. Regarding that, significant differences between treatments were observed, particularly for $\mathrm{K}$ and $\mathrm{Mg}$, probably due to the differences in the nutrient solutions and as a result of plant ionic adjustments. Despite that, mineral concentrations were within the normal range for pepper (Table S2) [6,38].

\subsection{Treatment Effect on P Accumulation and Efficiency Parameters for Trial 1 by Accessions}

Accessions were significantly affected by the NoP treatment, but not all to the same extent, as shown by the two-way ANOVA (Table S3) and the accession mean values for the evaluated traits (Table S4). For example, $[\mathrm{P}]_{\text {Root }}$ dropped as much as $91.62 \%$ and $90.53 \%$ for bol_037 and sp_cwr accessions, respectively, while for bol_144 the reduction was considerably lower (74.12\%) (Table 3). Regarding $[\mathrm{P}]_{\text {Shoot }}$, the most affected accessions were sp_piq $(-45.26 \%)$ and sp_cwr $(-45.03 \%)$, while some accessions experienced no statistically significant reduction of their shoot $\mathrm{P}$ concentration, e.g., bol_037, bol_144, eq_973, mex_pas, sp_bola and sp_cat (Table 3 and Table S4). Finally, for [P] $]_{\text {Fruit, }}$ only sp_bola showed no statistical difference between both treatments, whereas the remaining accessions represented significant reductions of around 35\% (Table 3).

In terms of $P$ tissue accumulation, significant differences were found among accessions. Thus, despite P-deficient plants had on average $86.16 \%$ less accumulated $\mathrm{P}$ in the root (RootP) than control plants, $56.12 \%$ less $\mathrm{P}$ in the shoots (ShootP), and $34.32 \%$ less in fruits (FruitP), some genotypes, such as bol_144 or eq_973, increased the amount of fruit accumulated P (although this was not statistically significant). Overall, plant total P (PTP) was reduced by $63.30 \%$; however, several genotypes experienced no statistically significant reduction of this trait, e.g., bol_037,bol_144_eq_973 and sp_bola, while others, like sp_mel, were highly affected (Table 3 and Table S4).

Furthermore, in order to evaluate how efficient genotypes were under these conditions parameters of physiological P use efficiency (PPUE), P efficiency ratio (PER), P uptake efficiency (PUpE) and P utilization efficiency (PUtE), were calculated $[18,21]$. Overall, PPUE was on average $36.26 \%$ higher under NoP conditions (Table 3). However, accessions' behavior for this parameter was extremely variable and significant differences between treatments were only found for two accessions, mu_esp (41.31\%) and sp_cwr (97.53\%) (Table 3 and Table S4). On the other hand, PER's behavior was more consistent and NoP treatment produced a generalized increase, averaging at $87.64 \%$ (Table 3 ). In this 
case, only two accessions showed no significant differences, bol_144 and sp_bola (Table 3 and Table S4). Interestingly, the best performers in terms of increasing PER from control to NoP conditions were California type accessions (sp_cat, sp_mel and sp_cwr) and Capsicum chinense accession eq_973.

In addition, an interesting amount of variability was observed for P uptake efficiency (PUpE) and $P$ utilization efficiency (PUtE) parameters (Figure 2). PUpE refers to the increase of internal P when it is available in the environment, whereas PUtE measures the ability of a genotype to increase its biomass per unit of internal P. Both measures always compare two conditions differing in $\mathrm{P}$ levels. PUpE averaged $96.56 \mathrm{mg} P$ for the whole collection, where accessions mex_scm (128.77 mg P), mu_esp (144.43 mg P), sp_cat (130.06 mg P), sp_piq (124.53 mg P) and usa_chi (108.70 mg P) showed the highest values of the experiment (Figure 2). PUtE values ranged from $29.77 \mathrm{~g} \mathrm{DW} \mathrm{g}^{-1} \mathrm{P}$ (bol_144) to $404.95 \mathrm{~g} \mathrm{DW} \mathrm{g}^{-1} \mathrm{P}$ (mex_pas) and averaged $186.55 \mathrm{~g}$ DW g $^{-1} \mathrm{P}$. Accessions mex_pas (404.95 g DW g ${ }^{-1}$ $\mathrm{P})$, usa_chi $\left(316.77 \mathrm{~g} \mathrm{DW} \mathrm{g}^{-1} \mathrm{P}\right)$ and sp_bola $\left(273.16 \mathrm{~g}^{\mathrm{DW} \mathrm{g}}{ }^{-1} \mathrm{P}\right)$ presented the most interesting results (Figure 2).

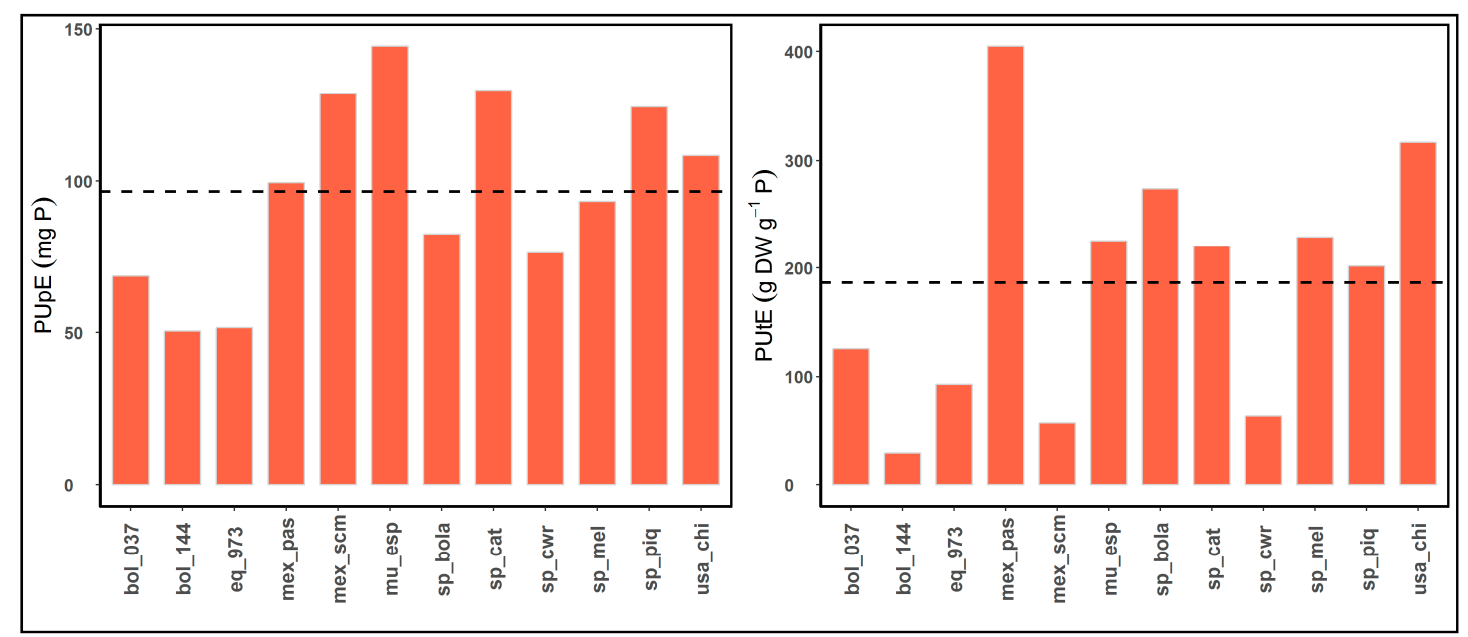

(A)

(B)

Figure 2. (A) Average PUpE (P Uptake Efficiency) and PUtE (P Utilisation Efficiency) values for the 12 accessions $(n=4)$ studied in Trial 1. (B) The black dashed line represents the average value for the whole collection for both PUpE (96.56 mg P) and PUtE (186.55 $\left.\mathrm{g} \mathrm{DW} \mathrm{g}^{-1} \mathrm{P}\right)$ parameters.

\subsection{Treatment Effect on Root and Shoot Biomass and Morphometrics for Trial 1 by Accessions}

$P$ is a major factor controlling root structure and architecture [20]. Hence, in order to understand the possible effects on plant morphology, root structure and architecture resulting from lack of $\mathrm{P}$, we compared several biomass and root traits.

Thus, roots dry weight (RW) showed a significant generalized decrease $(-24.52 \%)$ when genotypes were cultivated under NoP conditions compared to control plants (Table 3, Tables S3 and S4). This weight difference was more evident in lateral roots (LRW), which, on average, weighed $26.07 \%$ less, while root hairs (RHW) weight was $18.34 \%$ lower than under control conditions. Notwithstanding, the greatest weight difference was observed for shoot dry weight (SW), $-36.04 \%$ under NoP conditions (Table 3, Table S3 and Table S4). Despite that, taking a closer look at the treatment effect on biomass by accession, it is observed that only three accessions reduced it significantly in all organs: mex_pas, mu_esp and usa_chi. The rest of the accessions also reduced their biomass but not so systematically (Table 3 and Table S4). Interestingly, accession mex_scm, presented similar RW and SW under both treatments, while presenting the heaviest root system and shoot within the collection under NoP conditions (Table S4). Finally, root to shoot ratio (R/S) was positively affected under NoP treatment. This parameter increased by $20.94 \%$, on average, although only usa_chi showed statistically significant differences between treatments $(+22.73 \%)$ (Table 3$)$, apparently achieved by reducing a shoot's weight instead of increasing a root's weight (Table S4). 
Table 3. Accession behavior given by differences (\%) between control and NoP conditions for Trial 1 . Twenty different P accumulation and efficiency $(n=4)$, biomass and root traits $(n=9)$ and parameters were considered.

\begin{tabular}{|c|c|c|c|c|c|c|c|c|c|c|c|c|c|c|c|c|c|c|c|c|}
\hline \multirow[b]{2}{*}{ Accession } & \multicolumn{9}{|c|}{ P Accumulation and Efficiency Traits } & \multicolumn{6}{|c|}{ Biomass Traits } & \multicolumn{5}{|c|}{ Root Traits } \\
\hline & {$[P]_{\text {Root }}$} & {$[\mathrm{P}]_{\text {Shoot }}$} & {$[P]_{\text {Fruit }}$} & RootP & ShootP & FruitP & PTP & PPUE & PER & $\mathrm{RW}$ & LRW & RHW & SW & BW & $\mathrm{R} / \mathrm{S}$ & LRL & LRAD & RHW\% & PLFR & LRSL \\
\hline bol_037 & $-91.62 *$ & -32.10 & $-32.56^{*}$ & $-93.37 *$ & -37.32 & -25.00 & -54.72 & 95.23 & $106.37 *$ & -12.91 & -8.50 & -18.68 & -22.16 & -21.67 & 25.41 & 33.30 & -8.59 & -6.42 & 5.21 & 38.14 \\
\hline bol_144 & -74.12 * & -34.29 & -27.41 * & $-86.11 *$ & -55.45 & 98.52 & -51.66 & 90.59 & 78.15 & -26.94 & -36.58 & -1.37 & -8.13 & -4.08 & -16.22 & 15.14 & $-21.81 *$ & 51.06 & 9.56 & 112.94 \\
\hline eq_973 & $-87.67 *$ & -34.32 & $-35.19 *$ & $-87.60 *$ & -41.15 & 55.56 & -53.92 & 112.72 & 115.10 * & -21.00 & -30.62 & -3.38 & -16.21 & -14.17 & 6.67 & 49.55 & -16.80 & 39.34 & 6.02 & 78.20 \\
\hline mex_pas & $-78.01 *$ & 1.51 & -19.10 * & $-86.13 *$ & $-52.54 *$ & -59.45 & $-63.36^{*}$ & -27.82 & $36.65^{*}$ & $-36.24^{*}$ & $-42.38 *$ & -26.69 & $-59.65 *$ & -54.20 * & 27.89 & -3.07 & -9.83 & 12.06 & 6.63 & 70.84 \\
\hline mex_scm & -84.98 * & $-44.35 *$ & $-37.94 *$ & $-85.62 *$ & -62.45 * & -24.63 & $-57.57^{*}$ & 50.86 & $96.13 *$ & 0.65 & 9.15 & -8.95 & -18.18 & -12.62 & 21.37 & 8.86 & 7.98 & -11.28 & 1.63 & 16.26 \\
\hline mu_esp & $-77.38 *$ & $-32.15 *$ & $-33.93 *$ & $-88.61 *$ & $-77.91 *$ & -72.38 & $-76.17 *$ & $-41.31 *$ & 51.20 * & $-46.63 *$ & -29.39 & $-52.87 *$ & $-56.71 *$ & $-55.84 *$ & 9.88 & 26.88 & -8.57 & -12.76 & 7.36 & 115.25 \\
\hline sp_bola & -77.51 * & -4.11 & -17.47 & -75.94 * & -41.77 & -53.31 & -55.46 & -0.75 & 38.47 & -19.85 & $-30.22 *$ & -5.64 & -43.10 & -40.06 & 27.73 & 2.12 & -10.84 & 2.89 & 8.55 & 57.72 \\
\hline sp_cat & $-83.53 *$ & -24.27 & $-45.63 *$ & $-83.02 *$ & -56.11 & $-78.90 *$ & $-73.96 *$ & 27.80 & 108.33 * & -2.79 & -23.62 & 31.54 & -33.26 & -41.92 & 50.00 & 3.73 & -13.32 & 25.62 & 6.58 & 20.20 \\
\hline sp_cwr & $-90.53 *$ & $-45.03 *$ & $-47.21 *$ & $-92.86 *$ & $-55.30 *$ & -46.11 & $-61.87^{*}$ & $97.53 *$ & 132.69 * & $-19.90 *$ & -14.68 & -26.20 & -16.17 & -11.06 & -6.58 & $65.62 *$ & -7.13 & -6.42 & 4.17 & 91.05 \\
\hline sp_mel & -83.67 * & $-35.14 *$ & -49.43 * & $-87.27 *$ & -66.67 & -74.04 & $-77.17^{*}$ & 24.96 & 137.24 * & -30.17 & -35.41 & -21.27 & $-58.18^{*}$ & -48.90 & 63.81 & -10.47 & -3.90 & 11.05 & 3.12 & 54.84 \\
\hline sp_piq & $-75.52 *$ & $-45.26^{*}$ & $-44.11 *$ & $-78.51 *$ & $-59.93 *$ & -70.57 & $-67.78^{*}$ & 24.31 & 98.40 * & -25.14 & -17.60 & -32.96 & $-39.38 *$ & $-38.84 *$ & 18.59 & -19.76 & 4.76 & -14.57 & 0.98 & 6.84 \\
\hline usa_chi & $-76.56 *$ & -22.25 & $-32.20 *$ & $-88.89 *$ & $-66.88 *$ & $-61.56^{*}$ & $-65.95 *$ & -18.94 & $52.95 *$ & $-53.35 *$ & $-53.03 *$ & $-53.63 *$ & $-61.36^{*}$ & $-59.42 *$ & $22.73 *$ & 27.85 & 12.59 & -1.07 & -1.29 & 142.63 \\
\hline Global mean & $-81.76^{*}$ & $-29.31^{*}$ & $-35.18 *$ & $-86.16^{*}$ & $-56.12 *$ & $-34.32 *$ & $-63.30 *$ & $36.26^{*}$ & $87.64 *$ & $-24.52 *$ & $-26.07^{*}$ & $-18.34 *$ & $-36.04 *$ & $-33.56^{*}$ & $20.94 *$ & $16.65^{*}$ & $-6.29 *$ & 7.46 & 4.88 & 67.08 \\
\hline
\end{tabular}

Root $\mathrm{P}$ concentration $\left([\mathrm{P}]_{\text {Root }}\right)$, shoot $\mathrm{P}$ concentration $\left([\mathrm{P}]_{\text {Shoot }}\right)$, fruit $\mathrm{P}$ concentration $\left([\mathrm{P}]_{\text {Fruit }}\right)$, root total $\mathrm{P}$ content $($ Root $\mathrm{P})$, shoot total P content $($ ShootP), fruit total $\mathrm{P}$ content $($ FruitP), plant total P content (PTP), physiological P use efficiency (PPUE), P efficiency ratio (PER), total root dry weight (RW), lateral root dry weight (LRW), root hairs dry weight (RHW), shoot dry weight (SW), total biomass dry weight (BW), root to shoot ratio (R/S), lateral root total length (LRL), lateral root average diameter (LRAD), percentage of root dry weight devoted to root hairs (RHW\%), proportion of root length devoted to fine lateral roots (PLFR) and lateral root specific length (LRSL). * Indicates significant differences between treatments for that accession and trait. 
Regarding root morphology traits, treatment and accession effects showed significant influence over most traits, except for the percentage of root dry weight devoted to root hairs (RHW\%), for which significant differences between treatments were not detected (Table S3), despite there being differences among accessions. In addition, for lateral root specific length (LRSL), there was a significant accession per treatment interaction (Table S3). The significant effects of the NoP conditions on pepper's roots where to increase: the lateral root length (LRL), by $16.65 \%$, the proportion of root length devoted to fine lateral roots (PLFR), by $4.88 \%$, and the lateral root specific length (LRSL), by $67.08 \%$, and to decrease the root average diameter by $6.29 \%$.

Regardless of the general treatment effect, there were significantly different responses among genotypes (Table 3 and Table S4). It is worth to mention the significant increase of percentage of root length devoted to fine lateral roots (PLFR) and lateral root specific length (LRSL) observed in mu_esp and sp_bola (Table 3), with mu_esp having the higher absolute values for these traits of the whole collection under NoP conditions. Another interesting response was presented by accession bol_144, which outperformed the other genotypes for reducing its roots average diameter (21.81\%) and increase PLFR and LRSL under the NoP treatment.

\subsection{Principal Components Analysis for Trial 1}

Principal components analysis (PCA) was pursued in order to determine possible correlations between the response of the different measured traits to different inputs of $\mathrm{P}(\%$ of increase or decrease, as in Table 3), trying to demonstrate how accessions differed in terms of response to different $P$ levels. The first two principal components (PC) explained in combination $59.79 \%$ of the total variability (Figure 3A). Response in terms of total biomass dry weight (BW), physiological P use efficiency (PPUE), fruit total P content (FruitP), total shoot dry weight (SW), plant total P content (PTP), P efficiency ratio (PER) and root hairs dry weight (RHW), and values for $\mathrm{P}$ uptake efficiency (PUpE) and $\mathrm{P}$ utilization efficiency (PUtE) were the traits that contributed the most to the positive component of PC1, which explained $36.96 \%$ of the total variation. Response of lateral root average diameter (LRAD) and root total P content (RootP) were negatively correlated to PC1 (Figure 3A). Therefore, accessions plotted in the extreme right of the graph (Figure 3B), such as usa_chi, mu_esp, mex_pas and sp_piq, have in common that they have a great reduction in biomass when passing from control to NoP, and have good PUpE and PUtE. In other words, those are accessions that react very positively to any $\mathrm{P}$ addition to the soil but probably will not be appropriate to cultivate on poor soils (Figure 3B). At the same time, accession plotted at the upper most left part of the graph (Figure 3B), such as bol_144 and eq_973, are grouped for having high reductions in the total amount of $P$ in the roots with a high reduction in the diameter of the roots (LRAD) as adaptation to low $\mathrm{P}$, while having little difference in biomass under the two assayed conditions. In addition, PC2 explained $22.83 \%$ of variability with the response of lateral root dry weight (LRW), lateral root average diameter (LRAD), root dry weight (RW) and P utilization efficiency (PUtE) being the traits that contributed the most to it. Conversely, shoot $\mathrm{P}$ concentration $\left([\mathrm{P}]_{\text {Shoot }}\right)$, fruit $\mathrm{P}$ concentration $\left([\mathrm{P}]_{\text {Fruit }}\right)$ and shoot total $\mathrm{P}$ content $($ ShootP) were negatively correlated with PC2 (Figure 3A). Hence, accession located in the top part of the graph, such as mex_pas and sp_bola (Figure 3B), change the allocation of root resources, reducing the lateral root weight and diameter in situation of $\mathrm{P}$ restriction, maintaining the $\mathrm{P}$ level status of the shoots. On the contrary, the accessions located on the lower part of the graph such as mex_scm stand out by changing the level of $\mathrm{P}$ of the shoots and fruits $\left([\mathrm{P}]_{\text {Shoot }},[\mathrm{P}]_{\text {Fruit, }}\right.$, and ShootP) as a strategy to adapt to the low $\mathrm{P}$ conditions without modifying the lateral root morphology or size (Figure 3A). Interestingly, there was a cluster of parameters, such as the response in terms of $[\mathrm{P}]_{\text {Root }}, \mathrm{R} / \mathrm{S}$ and LRSL, indicating correlations among them. 


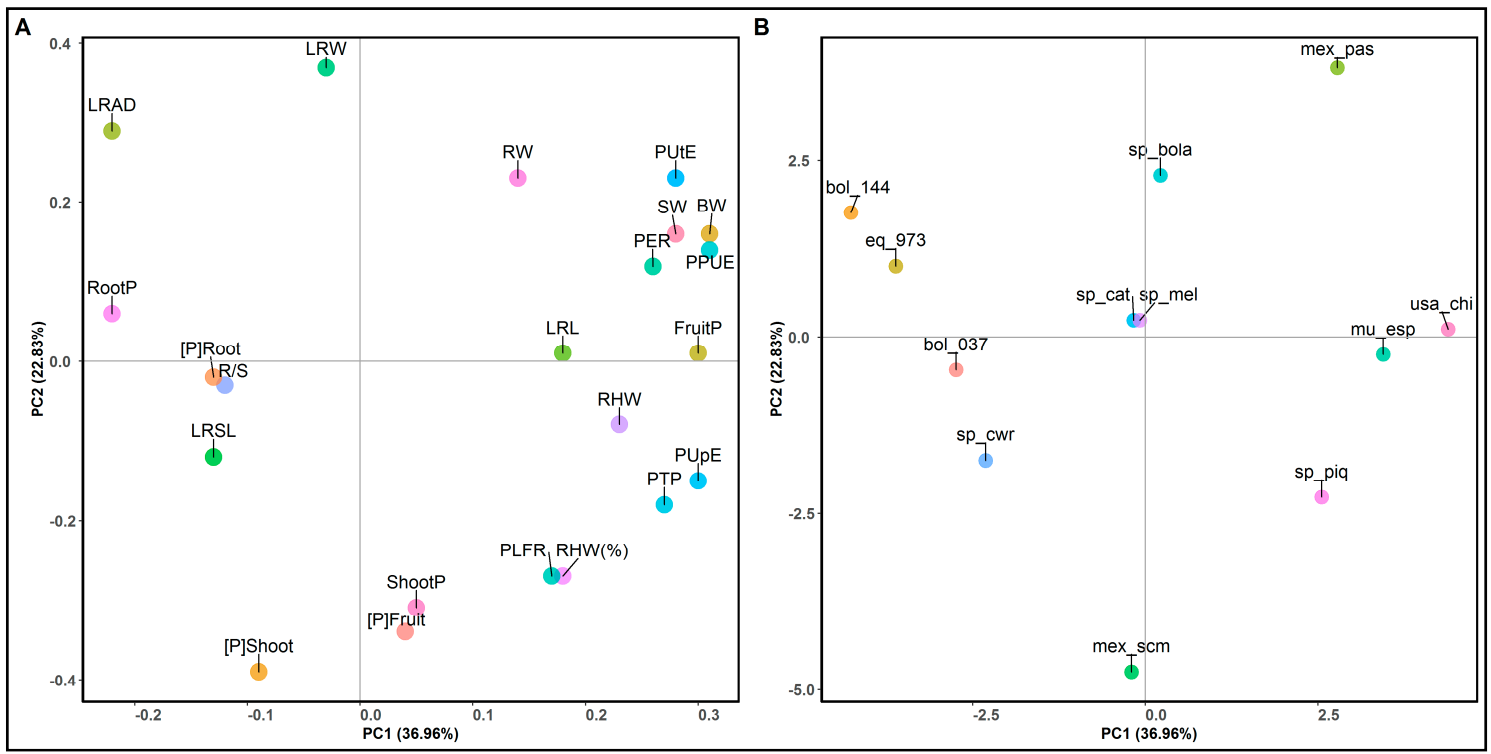

Figure 3. Principal Component Analysis (PCA) for the first two components based on trait differences between treatments for Trial 1. (A) Correlation between traits and the first two principal components. (B) Distribution of accessions based on studied traits. $\mathrm{P}$ tissue concentration traits $[\mathrm{P}]_{\text {Tissue }}, \mathrm{P}$ tissue total content traits RootP, ShootP, FruitP, plant total P content (PTP) trait, efficiency parameters PPUE (physiological P use efficiency), PER (P efficiency ratio), PUpE (P uptake efficiency) and PUtE (P utilization efficiency) and morphometric traits RW (root dry weight), LRW (lateral root dry weight), RHW (root hairs dry weight), SW (shoot dry weight), BW (total biomass dry weight), R/S (root to shoot ratio), LRL (lateral root length), LRAD (lateral root average diameter), RHW\% (root hairs dry weight \%), PLFR (proportion of length dedicated to fine roots) and LRSL (lateral root specific length) were considered.

Bearing these results, the second trial was designed. In it, five accessions from Trial 1 (mu_esp, mex_pas, sp_bola, sp_piq and mex_scm) were re-trialed and used as a comparison standard against 13 new $C$. annuum accessions. These genotypes were selected based on their above average $P$ uptake efficiency (PUpE) and P utilization efficiency (PUtE) scores and differential behavior against the lack of P. Note that an insufficient number of seeds to re-trial sp_cat and sp_mel, and the poor germination of usa_chi dictated their exclusion of Trial 2. The second trial was focused on checking the diversity within the germplasm belonging to Capsicum annuum species; for that reason, bol_144 and eq_973 were not selected, despite their interesting features. In this case, only P from the shoots was analyzed by a colorimetric protocol as a faster general measure of the P status of the plant, instead of a multi-elemental analysis by tissue. In addition, root hairs weight clustered together with P efficiency parameters was analyzed, and it was demonstrated that the lateral roots increase their length and reduce their diameter; thus, it was decided to analyze the root hairs' behavior as well. Both lateral and hair roots were scanned and analyzed (Figure 1).

\subsection{Treatment Effect on P Accumulation and Efficiency Parameters for Trial 2 by Accessions}

As in Trial 1, ANOVA showed that accession and treatment effects significantly affected P-related traits (Table S5). Interestingly, for physiological P use efficiency (PPUE) the accession effect was more important than treatment (Table S5). Remarkably, accession per treatment interaction was significant for a plant's total P content (PTP), PPUE and P efficiency ratio (PER) (Table S5). Accessions' individual variation between treatments are shown in Table 4 as $\left(\frac{\mu_{N o P}-\mu_{\text {Control }}}{\mu_{\text {Control }}}\right) \times 100 \%$ negative then indicating lower values under NoPtraits. To consult the accessions' mean values per treatment, please refer to Table S6. 
In Trial $2(n=6)$, all accessions but two showed significant differences between treatments for shoot $\mathrm{P}$ concentration $\left([\mathrm{P}]_{\text {Shoot }}\right)$, plant total P content (PTP) and P efficiency ratio (PER) showing an average reduction of $-31.5 \%$ and $-66.17 \%$, and an increase of $49.26 \%$, respectively (Table 4 ). Accessions mex_096D and sp_piq stood out for their substantial [P] $]_{\text {Shoot }}$ reduction and high PER value. In addition, accession sp_piq showed a significant reduction of its PTP level (-86.93\%), which, along with mex_scm $(-84.16 \%)$ and usa_sandia $(-87.88 \%)$, represented the highest reductions of the whole collection (Table 4). Contrarily, sp_lam and sp_lobo showed no differences between treatments regarding PTP (Table 4 and Table S6). In the case of PPUE, NoP treatment presented an average reduction of $24.98 \%$; however, significant differences were only detected for six accessions and with extremely erratic behavior within the collection; some accessions showed a reduction up to $72.75 \%$ (mex_scm), while others showed increases up to $45.04 \%$ (usa_jap).

Regarding P uptake efficiency (PUpE), average value was $298 \mathrm{mg}$ P, ranging from $63 \mathrm{mg}$ P (sp_lobo) to $796 \mathrm{mg} \mathrm{P}$ (usa_sandia). Accessions presenting above the average mean values were mex_096D, mex_103B, mex_ng, usa_conq and the re-trialed mex_scm and sp_piq (Figure 4). Contrarily to what happened in Trial 1, mu_esp was above the average for PUpE in this trial. Finally, average P utilization efficiency (PUtE) was $110 \mathrm{~g} \mathrm{DW} \mathrm{g}^{-1} \mathrm{P}$, while the minimum observed value was $43 \mathrm{~g}^{\mathrm{DW} \mathrm{g}}{ }^{-1} \mathrm{P}$ (sp_lam) and the maximum was $183 \mathrm{~g} \mathrm{DW} \mathrm{g}^{-1} \mathrm{P}$ (mex_pas). Like in Trial 1, accessions mex_pas (183 $\mathrm{g} \mathrm{DW} \mathrm{g}^{-1}$ $\mathrm{P})$ and sp_bola $\left(147 \mathrm{~g} \mathrm{DW} \mathrm{g}^{-1} \mathrm{P}\right)$ presented the best performance for this parameter (Figure 4).

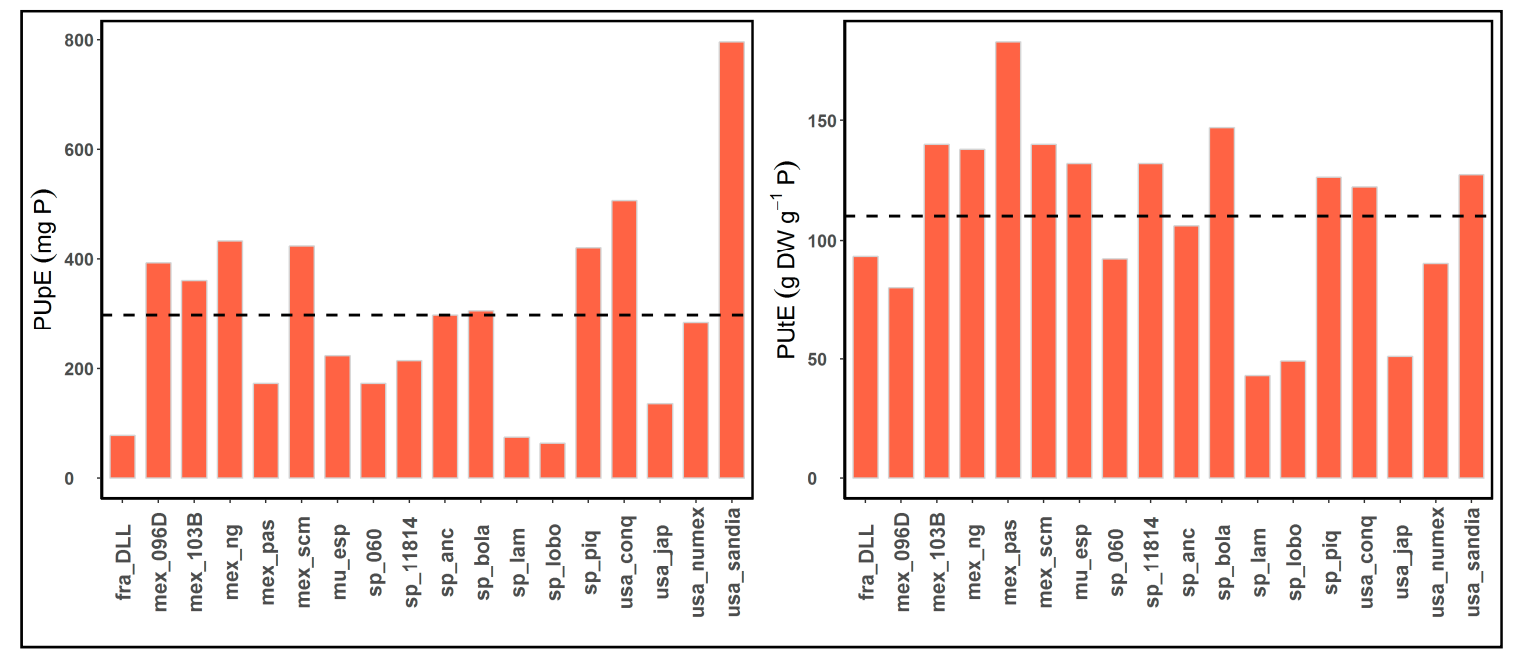

(A)

(B)

Figure 4. (A) Average P uptake efficiency (PUpE) and P utilization efficiency (PUtE) values for the 12 accessions studied in Trial $2(n=6)$. (B) Black dashed line represents average value for the whole collection for both PUpE (298 mg P) and PUtE (110 $\left.\mathrm{g} \mathrm{DW} \mathrm{g}^{-1} \mathrm{P}\right)$ parameters.

\subsection{Treatment Effect on Root and Shoot Biomass and Morphometrics for Trial 2 by Accessions}

In trial $2(n=6)$, multi-factorial ANOVA detected significant accession and treatment effects as well as the accession per treatment interaction for all biomass traits except root to shoot ratio (R/S) (Table S5). As expected, the effect of the NoP treatment led to lower dry weight accumulation of all sampled organs. This time, the most affected organs were the roots (RW, $-52.96 \%)$ and root hairs (RHW, $-59.10 \%$ ) (Table 4). The genotypes usa_sandia, mex_scm and sp_piq showed the highest biomass reduction when passing from control to NoP. On the contrary, fra_DLL, sp_lam, sp_lobo and usa_jap showed no statistical differences between treatments, although it is important to note that fra_DLL, sp_lobo, and sp_lam displayed the smallest plants within the collection for both treatments, which could explain their results. Accession usa_jap, on the other hand, showed medium-sized plants (Table S6). 
Table 4. Accession behavior given by differences (\%) between the control and NoP conditions for Trial 2. Twenty different P accumulation and efficiency, biomass and root traits $(n=6)$ and parameters were considered.

\begin{tabular}{|c|c|c|c|c|c|c|c|c|c|c|c|c|c|c|c|}
\hline \multirow[b]{2}{*}{ Accession } & \multicolumn{4}{|c|}{ P Accumulation and Efficiency Traits } & \multicolumn{6}{|c|}{ Biomass Traits } & \multicolumn{5}{|c|}{ Root Traits } \\
\hline & [P] Shoot & PTP & PPUE & PER & RW & LRW & RHW & SW & BW & $\mathrm{R} / \mathrm{S}$ & RTL & TAD & RHW\% & PFR & RSL \\
\hline fra_DLL & $-31.92 *$ & $-42.13^{*}$ & 25.76 & 48.75 * & -31.04 & -20.87 & -34.20 & -14.49 & -15.61 & -20.51 & 6.27 & 4.23 & -6.84 & -0.31 & 58.00 \\
\hline mex_096D & $-44.10 *$ & $-74.54 *$ & 8.80 & $87.88^{*}$ & $-42.62 *$ & $-29.17 *$ & $-50.76 *$ & $-49.18 *$ & $-48.86 *$ & 27.27 & -0.69 & 2.96 & -19.79 * & -2.46 & 71.79 * \\
\hline mex_103B & $-25.45 *$ & $-68.35 *$ & $-42.41 *$ & $33.91 *$ & $-63.97 *$ & $-57.22 *$ & $-68.38 *$ & $-56.97 *$ & $-57.48 *$ & -4.26 & -10.44 & $-7.53 *$ & -10.29 & $5.91 *$ & 131.10 * \\
\hline mex_ng & $-38.75 *$ & $-80.58 *$ & -53.53 & $66.18 *$ & $-70.25 *$ & $-68.60 *$ & $-71.38 *$ & $-69.72 *$ & $-69.75 *$ & 7.95 & -0.06 & $-13.30 *$ & -7.35 & $9.79 *$ & 229.58 * \\
\hline mex_pas & -11.63 & $-54.71 *$ & $-39.68 *$ & 14.69 & $-45.43 *$ & $-37.30 *$ & -52.56 * & $-48.13 *$ & $-47.97 *$ & 13.16 & 6.22 & -0.80 & -11.40 & 1.83 & $81.25 *$ \\
\hline mex_scm & $-24.46^{*}$ & $-84.16^{*}$ & -72.75 * & 30.99 * & -71.09 * & -53.17 * & $-79.62 *$ & -79.40 * & -78.97 * & 60.71 & -15.45 & -0.72 & -21.79 & 2.51 & 96.42 \\
\hline mu_esp & $-28.78 *$ & $-76.55^{*}$ & -45.93 & $41.15 *$ & $-58.48 *$ & $-36.78 *$ & $-66.55 *$ & $-64.64 *$ & $-64.02 *$ & 33.93 & 83.39 & $-8.37 *$ & -16.18 & $6.53 *$ & 293.57 * \\
\hline sp_060 & $-23.21 *$ & $-57.00 *$ & -19.84 & 30.93 * & $-58.36^{*}$ & $-32.94 *$ & $-64.94 *$ & $-41.59 *$ & $-41.30 *$ & $-24.24 *$ & 17.90 & -1.52 & -18.90 & 5.90 & 181.31 * \\
\hline sp_11814 & $-27.72 *$ & $-66.80 *$ & -40.61 & $34.34 *$ & $-54.26 *$ & $-9.84 *$ & $-65.36^{*}$ & $-55.36^{*}$ & $-54.65 *$ & -6.46 & 110.07 & -0.85 & -21.27 * & 3.37 & 282.31 * \\
\hline $\mathrm{sp}_{\text {anc }}$ & $-35.55 *$ & $-66.88 *$ & -20.37 & $53.60 *$ & $-47.93 *$ & $-37.11 *$ & $-53.30 *$ & $-48.66 *$ & $-48.08 *$ & 2.94 & -9.82 & -5.51 & -7.61 & 6.16 & 44.62 \\
\hline sp_bola & $-29.23 *$ & $-78.82 *$ & -59.09 * & 41.52 * & $-63.73 *$ & $-6.21 *$ & -73.15 * & -70.90 * & $-70.35 *$ & 23.08 & 52.67 & -3.10 & -26.14 * & 4.62 & 261.22 * \\
\hline sp_lam & $-30.84 *$ & -36.71 & 29.12 & $42.54 *$ & -35.96 & -24.57 & -42.23 & -7.24 & -10.66 & $-30.56 *$ & -7.73 & 2.45 & -8.40 & 0.22 & 38.68 \\
\hline sp_lobo & -24.83 & -35.31 & 16.75 & 31.29 & -13.58 & -9.56 & -15.06 & -14.14 & -10.95 & 6.90 & 20.75 & -7.69 & -0.93 & $8.97 *$ & 27.40 \\
\hline sp_piq & $-42.48 *$ & $-86.93 *$ & $-50.75 *$ & $91.29 *$ & $-72.33 *$ & $-51.80 *$ & $-79.12 *$ & $-75.78 *$ & $-75.48 *$ & 8.33 & 4.58 & 3.29 & -21.96 * & 2.35 & $220.45 *$ \\
\hline usa_conq & $-38.95 *$ & $-79.74 *$ & -47.09 & $61.46^{*}$ & $-59.27^{*}$ & $-41.08 *$ & $-65.12 *$ & $-67.50 *$ & $-66.97 *$ & 13.04 & 3.73 & -8.02 & -14.25 & 8.23 & 122.83 * \\
\hline usa_jap & $-39.15^{*}$ & $-49.02 *$ & 45.04 & 68.30 * & -48.83 & -23.47 & -60.76 & -13.55 & -15.53 & $-45.95 *$ & 9.01 & -0.44 & -21.29 & 0.00 & 72.51 * \\
\hline usa_numex & $-33.47 *$ & $-64.88 *$ & -17.21 & $50.09 *$ & $-49.78 *$ & $-38.25 *$ & $-53.04 *$ & $-45.86^{*}$ & $-46.10 *$ & -9.52 & $-39.33^{*}$ & 8.76 & -7.89 & -3.70 & 21.77 \\
\hline usa_sandia & $-36.52 *$ & $-87.88^{*}$ & $-65.94 *$ & $57.77^{*}$ & $-66.39 *$ & $-59.05 *$ & $-68.20 *$ & $-80.15^{*}$ & $-79.31 *$ & 66.67 & 10.55 & 1.80 & -10.35 & 0.10 & 262.06 \\
\hline Global mean & $-31.50 *$ & $-66.17^{*}$ & $-24.98 *$ & $49.26 *$ & $-52.96 *$ & $-35.39 *$ & $-59.10 *$ & $-50.18 *$ & $-50.11 *$ & 6.80 & 13.42 & -1.91 & $-14.03 *$ & $3.33 *$ & $138.71 *$ \\
\hline
\end{tabular}

Shoot P concentration ([P $]_{\text {Shoot }}$ ), plant total P content (PTP), physiological P use efficiency (PPUE), P efficiency ratio (PER), total root dry weight (RW), lateral root dry weight (LRW), root hairs dry weight (RHW), shoot dry weight (SW), total biomass dry weight (BW), root to shoot ratio (R/S), root total length (RTL), total root average diameter (TRAD), percentage of root dry weight devoted to root hairs (RHW\%), proportion of root length devoted to fine roots (PFR) and root specific length (RSL). * Indicates significant differences between treatments for that accession and trait. 
All root parameters were significantly affected by the accession effect, while only a percentage of root hairs (RHW\%), proportion of root length devoted to fine roots (PFR) and root specific length (RSL) were significantly affected by the treatment. For root total length (RTL), accession usa_numex $(-39.33 \%)$ was the only genotype that significantly reduced its root length, while the general population tendency was to increase it (Table 4). Accessions mex_103B (-7.53\%), mex_ng $(-13.30 \%)$ and mu_esp $(-8.37 \%)$ significantly decreased their total average diameter under NoP conditions (Table 4) in accordance with the population general trend $(-1.91 \%)$. Likewise, the percentage of root dry weight devoted to root hairs (RHW\%) was 14.03\% lower under P-stress conditions, with accessions mex_096D (-19.79\%), sp_11814 $(-21.27 \%)$, sp_bola $(-26.14 \%)$ and sp_piq $(-21.96 \%)$ being the significantly affected ones (Table 4). Contrarily, the proportion of root length devoted to fine roots (PFR) showed a slight increase under NoP $(3.33 \%)$, compared to control conditions, although only four accessions were significantly affected. Thus, accessions mex_103B (5.91\%), mex_ng (9.79\%), mu_esp (6.53\%) and sp_lobo (8.97\%) significantly increased this parameter under NoP conditions (Table 4). Ultimately, root specific length (RSL) was, on average, $138.71 \%$ higher under NoP conditions. Most accessions were significantly affected by the treatment; mu_esp (293.57\%) and sp_11814 (282.31\%) were the accessions with a higher increase for root specific length (Table 4).

\subsection{Principal Components Analysis for Trial 2}

The first two PCs explained 63.84\% of total variation for Trial 2 (Figure 5). PC1 explained $47.48 \%$ of the total variation and was defined by the response of total biomass dry weight (BW), shoot dry weight (SW), physiological P use efficiency (PPUE), plant total P content (PTP), root dry weight (RW), root hair dry weight (RHW) and absolute values for P uptake efficiency (PUpE), while the traits that most contributed negatively were the response of the root to shoot ratio $(R / S)$ and root specific length (RSL) (Figure 5A). PC2 on the other hand explained $16.36 \%$ of total variability and was positively correlated with response of shoot $\mathrm{P}$ concentration $\left([\mathrm{P}]_{\text {Shoot }}\right)$, proportion of root length devoted to fine lateral roots (PFR) and root total length (RTL), while being negatively correlated with the total root average diameter (TAD) and P efficiency ratio (PER) (Figure 5A).

Based on those results, accessions located at the right side of the graph (usa_sandia, mex_ng, sp_piq, usa_conq, mex_scm and mex_103B), presented an important biomass reduction under NoP conditions and, at the same time, interesting PUpE and PUtE values and an increase at the R/S and RSL level when in NoP, indicating that these are good candidates for high input conditions due to their excellent response to the addition of $\mathrm{P}$ through fertilization (Table 4 and Figure 5B). On that matter, usa_sandia stood out for its impressive PUpE values and high increase of $R / S$ and high increase of RSL (Figure 4B). On the opposite side, sp_lam, fra_DLL and usa_jap accessions were located, with negative values of R/S and relative low increase of RSL (Figure 5B) and poor values for PUpE and PUtE. From this group, usa_jap and fra_DLL had good values of biomass under NoP (Table S6). Altogether, this indicates that they perform well under NoP conditions but do not improve with additional units of P. Furthermore, in the upper part of the graph, accessions usa_numex and mex_096D were characterized by decreasing the P concentration in the shoot $\left([\mathrm{P}]_{\text {Shoot }}\right)$, and thus, increasing PER, and having higher root's total length (RTL), proportion of length dedicated to fine roots (PFR) and root diameter (TAD) in the control than in NoP conditions (Table 4 and Figure 5B). Finally, on the bottom part of the plot, accessions mu_esp, mex_pas, sp_11814 and sp_bola were positively correlated with changes in TAD and PER and high values of PUtE, indicating a tendency to reduce their roots' average diameter while maintaining the shoot $[\mathrm{P}]$ concentration (Table 4 and Figure $5 \mathrm{~B}$ ). 


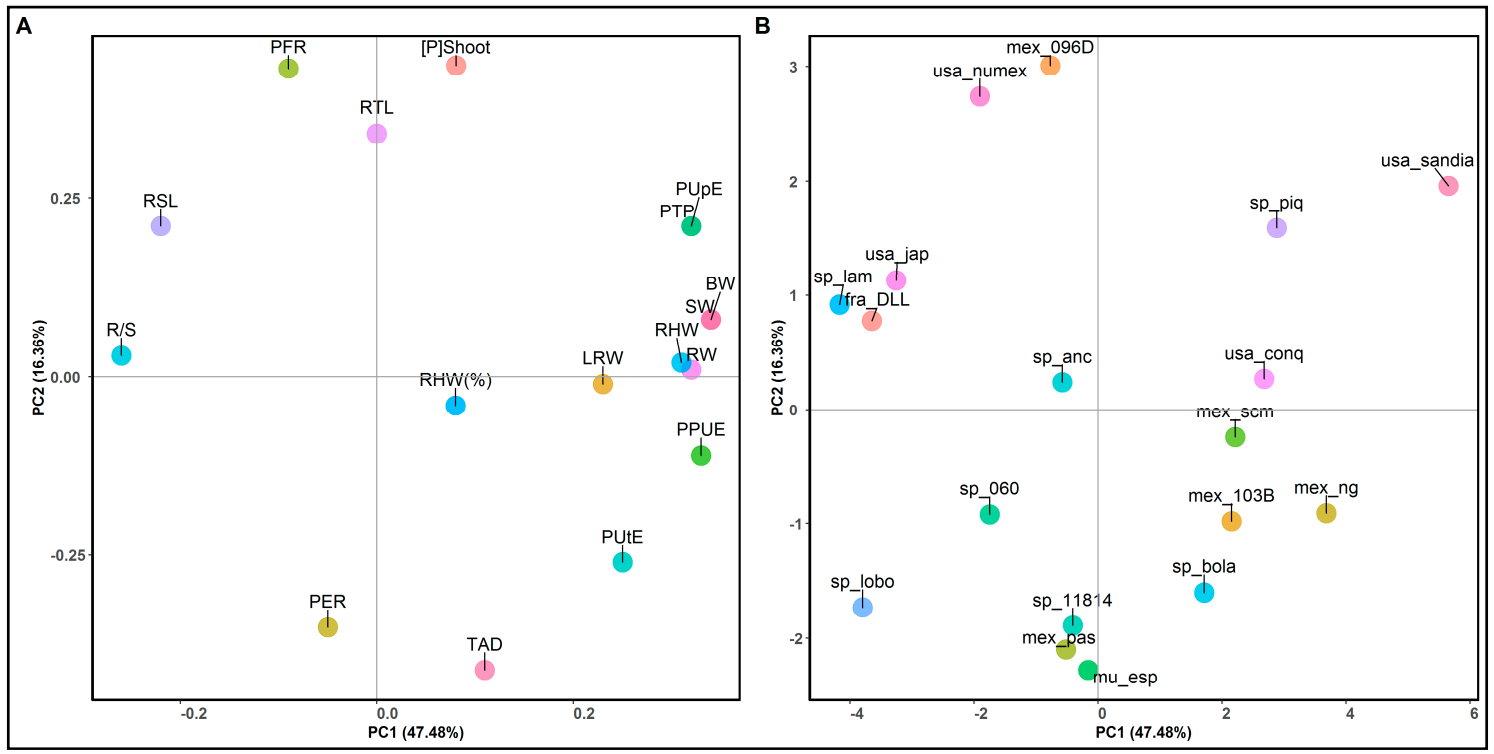

Figure 5. PCA based on trait increments between treatments for the Trial 2 experiment. (A) Correlation between traits and the first two principal components. (B) Distribution of accessions based on the studied traits. $\mathrm{P}$ tissue concentration traits $[\mathrm{P}]_{\text {Shoot}}, \mathrm{P}$ total plant content $(\mathrm{PTP})$ trait, efficiency parameters PPUE (physiological P use efficiency), PER (P efficiency ratio), PUpE (P uptake efficiency) and PUtE (P utilization efficiency) and morphometric traits RW (root dry weight), LRW (lateral root dry weight), RHW (root hairs dry weight), SW (shoot dry weight), BW (total biomass dry weight), R/S (root to shoot ratio), RTL (root total length), TAD (root total average diameter), RHW\% (root hairs dry weight \%), PFR (proportion of length dedicated to fine roots) and RSL (root specific length) were considered.

\section{Discussion}

\subsection{Peppers Change Their Mineral Homeostasis and re-Allocate Their P Reserves to Adjust to Low-P Conditions}

A comparison of $\mathrm{P}$ (root, shoot and fruit in Trial 1 and just shoot in Trial 2) concentrations provided relevant information on the impact of the different levels of $\mathrm{P}$ on pepper. There is evidence to suggest that pepper plant organs require $\mathrm{P}$ in different amounts, and the minimum levels are drastically different between tissues. Regarding that, roots presented the highest drop of $P$ concentrations between treatments, indicating that they are able to mobilize $\mathrm{P}$ in order to benefit above-ground biomass. This response has been described in other crops, in which physiological and morphological changes, such as changes in root porosity and aerenchyma proportion, have been reported as mechanisms for reducing both the metabolic expenses and $\mathrm{P}$ requirements of the root system, while maintaining the foraging ability $[15,22,39]$. Interestingly, there were also differences among genotypes on P-tissue allocation, which opens the door to breeding materials with minimal P levels in the fruits and less need for fertilization without hampering production. For instance, some authors believe that we consume more $\mathrm{P}$ than required for a healthy diet, and often in the form of phytate, which is not fully absorbed by the human digestive system $[40,41]$.

Homeostatic processes by which plants take up, transport and store nutrients are not independent, and therefore, the absence or excess of some elements can affect how the rest are processed, as was observed herein $[6,38,39]$. However, despite some significant differences between treatments for other macro minerals and tissue combinations, the values observed for this experiment are within the normal range, and therefore, no deficiency or excess was detected apart from P [6,42]. 


\subsection{P Efficiency Parameters Measure Different Aspects of the Plant Response}

The use of parameters to describe a plant's mineral uptake and use efficiency is a widely adopted practice in this scientific field $[18,21]$. Thus, physiological P use efficiency (PPUE) provides information on how productive a genotype may be, based on its tissues $\mathrm{P}$ concentration under a specific treatment; hence, high values indicate higher efficiency transforming absorbed P into biomass. Under these conditions, accessions mex_pas (control) and bol_144 (NoP) presented the highest PPUE for Trial 1, whereas in Trial 2, usa_sandia and fra_DLL presented the highest values for control and NoP, respectively. These results indicate a differential response, making these accessions interesting candidates for different P-fertilizers input conditions (e.g., high and low). Interestingly, the general response of increasing PPUE from control to NoP was not observed for trial 2. It is important to point out that although it is the same parameter, it was calculated in a different way depending on the trial. For Trial 1, concentration of $\mathrm{P}$ was a mean of all plant tissues whereas for Trial 2 it was extrapolated from shoot only, which may have caused a behavior distortion. P efficiency ratio (PER), on the other hand, relates the amount of yielded biomass with the amount of accumulated $\mathrm{P}$ in the plant; thus, high values indicate a higher ability to generate biomass with less P. Thus, bol_144 (Trial 1) and fra_DLL (Trial 2) are extremely efficient genotypes, especially under low-input conditions. These results indicate an interesting ability to use every unit of absorbed $\mathrm{P}$ and convert it into biomass and suggest that aptitude should be used in low-input systems.

Regarding P uptake efficiency (PUpE), accessions mex_scm and sp_piq showed an above average performance in both trails, although in the Trial 2 both usa_conq and usa_sandia showed higher values. This indicates that these accessions responded well to fertilization and were able to take up high amounts of $P$ when it is present. In terms of $P$ utilization efficiency (PUtE), accessions mex_pas and sp_bola showed the highest values in both trials, indicating that they are able to use the absorbed $\mathrm{P}$ into biomass generation more efficiently than the rest of the accessions. Furthermore, genetic variation regarding P acquisition and use efficiency has been widely reported in soybean, maize, sunflower, brassica and melon $[15,18,21,43,44]$. However, to our knowledge, this is the first work that provides such information for pepper germplasm. Herein, a wide range of variability is reported regarding $\mathrm{P}$ efficiency parameters, as well as several combinations among them, offering numerous possibilities for breeding for improved P uptake and P use efficiency parameters (PUE). Several authors have reported independence between uptake and use efficiency, which enables the improvement of both as well as selecting materials with different purposes (e.g., high- and low-input environments) [12,18,21,44]. These results seem to point towards that idea, since both parameters were located separately in both trials' PCA.

\subsection{Modifications at Root Level}

Many species promote root instead of aerial growth in order to enhance foraging capability $[15,17,21]$. In this experiment, a loss of root mass was observed under NoP conditions; however, this reduction was lower than that of the aerial part. This resulted in an increased root to shoot ratio under NoP conditions compared to control plants. The results indicate that, apart from lower biomass accumulation and redistribution of it, there are important modifications, particularly at root level, that help the plant to cope with P-stress. This was also observed in previous works with other crops for P-starvation conditions [20].

Morphological adaptations to low $\mathrm{P}$ concentrations in the soil aim at enhancing $\mathrm{P}$ acquisition by enabling exploitation of a greater soil volume, as well as enhancing P uptake without significantly increasing metabolic costs $[17,18,45,46]$. This is achieved mainly by the stimulation of root hairs $[15,18,45]$, by halting secondary growth of the root and promoting primary growth and elongation [46] or increasing porosity and aerenchyma in roots [22]. Herein, lateral root length (LRL), but not total root length (RTL), increased under NoP conditions. It seems that lateral root elongation was a key response of the plant to reach possible $\mathrm{P}$ patches in the soil. This response has been described as an adaptive response to low $\mathrm{P}$ in Phaseolus vulgaris [46]. Other parameters, 
such as the lateral root specific length (LRSL), root specific length (RSL), percentage of fine roots (PFR) and percentage of fine lateral roots (PFLR), were higher under NoP, whereas the LRAD was lower. Therefore, pepper genotypes react to low $\mathrm{P}$ by producing thinner and lighter roots (with less carbon cost), which is in concordance with the literature $[15,18,45,47]$. On that regard, bol_144 (Trial 1) and mex_ng (Trial 2) stood out for their significant reduction of root average diameter while increasing the proportion of length dedicated to thinner roots under NoP conditions. In addition, accessions such as mu_esp and sp_bola showed a significant stimulation of their root specific length and proportion of length dedicated to thinner roots under the NoP conditions, despite presenting a lower root weight than under control conditions.

Although the percentage of root hair weight (RHW\%) decreased in Trial 2, and was not significantly different in Trial 1, it must be pointed out that this measure includes fine roots and not specifically root hairs; therefore, it must be investigated if root hairs are modified in pepper under contrasting $\mathrm{P}$ conditions. Analyzing roots is a difficult task, and specific protocols must be set up to increase accuracy of root traits' study. The differences regarding root scanning and the analysis procedure between trials indicate that the first methodology (scanning just lateral roots) was more effective in finding root responses, since scanning all the fine roots has technical limitations.

\subsection{A Wide Range of Responses to Breed Efficient Genotypes}

Despite the general responses of pepper to low P described in the previous section, there was a wide range of responses depending on the accession studied. PCA's projection showed a widely differentiated behavior among accessions, creating several accession clusters depending on their overall response to NoP. For example, sp_piq, mex_scm, usa_sandia, usa_conquistador and mex_ng showed high PUpE values associated with increases in root to shoot ratio and root specific length. Sp_bola, mex_pas and mu_esp were associated with high PUtE values, no changes in their concentration of P in the shoots, reduction of the root diameter and an increase of percentage of fine roots and root total length. On the other hand, there were accessions that were poorly responsive to the changes in P levels, such as bol_37 and eq_973, or sp_lam, fra_DLL or usa_jap. Results indicated that some accessions were more suited to grow under low input conditions (bol_144, eq_973 and usa_jap) and others were highly responsive to increasing amounts of $\mathrm{P}$ available in the soil (sp_piq, sp_pas and mu_esp). It was also observed that $P$ uptake efficiency and $P$ utilization efficiency seem to be controlled independently, and here, this is demonstrated by the positioning of both parameters in opposite quadrants of the PCAs' second component, and accessions with contrasting levels.

On that matter, the availability of diversity is of paramount importance for crop breeding, enabling the combination of several favorable traits or behaviors in a single genotype, which in return can be a more effective solution than to have those traits in separate genotypes. For example, Miguel et al. [48] demonstrated, in common bean, that combining shallow basal roots and long root hairs yielded a larger effect regarding $\mathrm{P}$ acquisition than their additive effects separately. Breeding for efficient genotypes needs an accurate definition of the target to be improved; this is not the same as improving the ability to grow under low inputs than reacting favorably to $\mathrm{P}$ addition. Defining the best ideotype to each condition and the combination of different adaptation opens the possibility to breed towards different goals $[12,18,21,44]$.

\section{Conclusions}

Herein, a diverse collection of 25 pepper accessions has been characterized for their behavior under P low-input conditions. A considerable amount of diversity has been reported for the response to phosphorus low-input conditions for several phosphorus uptake and use efficiency parameters, and root and biomass traits. Evidence suggests that $\mathrm{P}$ low-input conditions play an important role in the plant's tissues allocation for this mineral and that different organs show different critical levels of phosphorus. In addition, the responses of this collection indicate the existence of genetic diversity, which may be used in breeding programs to generate materials with different applications. 
Accessions bol_144 and fra_DLL showed promising results for low-input conditions, whereas mex_scm, sp_piq, usa_conq and usa_sandia were on the opposite spectrum and are probably best used under high-input conditions due to their uptake efficiency. In addition, mex_pas and sp_bola showed the best results regarding $\mathrm{P}$ use efficiency. Finally, P low-input conditions proved to be an important factor controlling root morphology. Under these conditions, roots presented longer and thinner roots. These traits correlated to a higher efficiency and biomass accumulation under P-starving conditions. This work provides relevant first insights into pepper's response to phosphorus low-input conditions. More works are needed in order to dissect the mechanisms controlling the response, and consequently, to be introgressed into new materials.

Supplementary Materials: The following are available online at http://www.mdpi.com/2073-4395/10/5/637/s1, Table S1: Ion concentrations for irrigation water, Control and NoP solutions used in both Trial 1 and Trial 2. Table S2: Effect of Control and NoP treatments on P, K, Ca, Mg, Na and S (g/100g DW) concentrations for root, shoot and fruit tissues for Trial 1. Overall mean values, standard deviation and $p$-value for each plant tissue and treatment are provided. Table S3: Trial 1 multi-factor ANOVA's mean square values of accession and treatment effects, their interaction, and error for $\mathrm{P}$ concentration traits $[\mathrm{P}]_{\text {Root }},[\mathrm{P}]_{\text {Shoot }},[\mathrm{P}]_{\text {Fruit }}, \mathrm{P}$ content traits RootP $(\mathrm{g} \mathrm{P})$, ShootP (g P), FruitP (g P), PTP (mg P), P efficiency parameters PPUE $\left(g^{2}\right.$ DW g $\left.{ }^{-1} \mathrm{P}\right)$ and PER $\left(g\right.$ DW g $\left.{ }^{-1} \mathrm{P}\right)$ and for morphometric traits RW (g), LRW (g), RHW(g), SW (g), BW (g), R/S, LRL (m), LRAD (mm), RHW\% (\%), PLFR (\%) and LRSL (m/g). Table S4: Trial 1 mean values and standard deviation for P accumulation and efficiency traits and parameters, and biomass and root traits and parameters. Table S5: Trial 2 multi-factor ANOVA's mean square values of accession $(\mathrm{A})$ and treatment $(\mathrm{T})$ effects, their interaction and error $(\mathrm{E})$ for $\mathrm{P}$ concentration trait [P]Shoot, P content trait PTP (mg P), for efficiency parameters PPUE $\left(\mathrm{g}^{2} \mathrm{DW} \mathrm{g} \mathrm{g}^{-1} \mathrm{P}\right)$ and PER $\left(\mathrm{g} \mathrm{DW} \mathrm{g}^{-1} \mathrm{P}\right)$ and for morphometric traits RW (g), LRW (g), RHW (g), SW (g), BW (g), R/S, RTL (m), TAD (mm), RHW\%, PFR (\%) and RSL (m/g). Table S6: Trial 2 mean values and standard deviation for P accumulation and efficiency traits and parameters, and biomass and root traits and parameters.

Author Contributions: Conceptualization, methodology and validation: A.F., Á.C. and A.R.-B.; Data curation: L.P.-D. and D.G.-V.; Formal analysis and investigation: L.P.-D., D.G.-V., V.C.-Z. and A.Q.; Resources, funding acquisition and project administration: A.F. and Á.C.; Writing-original draft: L.P.-D. and A.F.; Writing-review and editing: L.P.-D., D.G.-V., V.C.-Z., A.Q., Á.C., A.R.-B. and A.F. All authors have read and agreed to the published version of the manuscript.

Funding: This research was funded by FEDER-Funds and INIA, grant number RTA2013-00022-C02-02. The APC was self-funded.

Acknowledgments: Authors thank seed providers included in Table 1, such as P.W. Bosland, François Jourdan and the different Regulatory Boards of the PDOs and GPIs included in this study. Additionally, we want to thank Jose J. Luna for his advice on Mexican peppers.

Conflicts of Interest: The authors declare no conflict of interest. The funders had no role in the design of the study; in the collection, analyses or interpretation of data; in the writing of the manuscript, or in the decision to publish the results.

\section{References}

1. Jaggard, K.W.; Qi, A.; Ober, S. Possible changes to arable crop yields by 2050. Philos. Trans. R. Soc. B Biol. Sci. 2010, 365, 2835-2851. [CrossRef] [PubMed]

2. Grafton, R.Q.; Daugbjerg, C.; Qureshi, M.E. Towards food security by 2050. Food Secur. 2015, 7, 179-183. [CrossRef]

3. Tilman, D.; Cassman, K.G.; Matson, P.A.; Naylor, R.; Polasky, S. Agricultural sustainability and intensive production practices. Nature 2002, 418, 671-677. [CrossRef] [PubMed]

4. Tsiafouli, M.A.; Thébault, E.; Sgardelis, S.P.; de Ruiter, P.C.; van der Putten, W.H.; Birkhofer, K.; Hemerik, L.; de Vries, F.T.; Bardgett, R.D.; Brady, M.V.; et al. Intensive agriculture reduces soil biodiversity across Europe. Glob. Chang. Biol. 2015, 21, 973-985. [CrossRef] [PubMed]

5. Raza, A.; Razzaq, A.; Mehmood, S.S.; Zou, X.; Zhang, X.; Lv, Y.; Xu, J. Impact of climate change on crops adaptation and strategies to tackle its outcome: A review. Plants 2019, 8, 34. [CrossRef] [PubMed]

6. Jones, J.B.J. Plant Nutrition and Soil Fertility Manual, 2nd ed.; Press, C., Ed.; Taylor \& Francis Group: Boca Raton, FL, USA, 2012; ISBN 9781439816103.

7. Schnug, E.; Haneklaus, S.H. Assessing the plant phosphorus status. In Phosphorus in Agriculture: 100\% Zero; Springer: Dordrecht, The Netherlands, 2016; pp. 95-125. 
8. Vance, C.P.; Uhde-Stone, C.; Allan, D.L. Phosphorus acquisition and use: Critical adaptations by plants for securing a nonrenewable resource. New Phytol. 2003, 157, 423-447. [CrossRef]

9. Cordell, D.; Drangert, J.O.; White, S. The story of phosphorus: Global food security and food for thought. Glob. Environ. Chang. 2009, 19, 292-305. [CrossRef]

10. Mogollón, J.M.; Beusen, A.H.W.; van Grinsven, H.J.M.; Westhoek, H.; Bouwman, A.F. Future agricultural phosphorus demand according to the shared socioeconomic pathways. Glob. Environ. Chang. 2018, 50, 149-163. [CrossRef]

11. Schnug, E.; Haneklaus, S.H. The enigma of fertilizer phosphorus utilization. In Phosphorus in Agriculture: 100\% Zero; Springer: Dordrecht, The Netherlands, 2016; pp. 7-26.

12. Lynch, J.P. Roots of the second green revolution. Aust. J. Bot. 2007, 55, 493-512. [CrossRef]

13. Fernández, J.M.; Selma, M.A.E. Estimación de la contaminación agrícola en el Mar Menor mediante un modelo de simulación dinámica. In Proceedings of the El Agua y Sus Usos Agrarios; Universidad de Zaragoza: Zaragoza, Spain, 1998; Volume 9, pp. 1-9.

14. Kauranne, L.-M.; Kemppainen, M. Urgent need for action in the Baltic sea area. In Phosphorus in Agriculture: 100\% Zero; Springer: Dordrecht, The Netherlands, 2016; pp. 1-6.

15. Fernández, M.C.; Rubio, G. Root morphological traits related to phosphorus-uptake efficiency of soybean, sunflower, and maize. J. Plant Nutr. Soil Sci. 2015, 178, 807-815. [CrossRef]

16. Fita, A.; Bowen, H.C.; Hayden, R.M.; Nuez, F.; Picó, B.; Hammond, J.P. Diversity in expression of Phosphorus (P) responsive genes in Cucumis melo L. PLoS ONE 2012, 7, e35387. [CrossRef]

17. Li, J.; Xie, Y.; Dai, A.; Liu, L.; Li, Z. Root and shoot traits responses to phosphorus deficiency and QTL analysis at seedling stage using introgression lines of rice. J. Genet. Genom. 2009, 36, 173-183. [CrossRef]

18. Hammond, J.P.; Broadley, M.R.; White, P.J.; King, G.J.; Bowen, H.C.; Hayden, R.M.; Meacham, M.C.; Mead, A.; Overs, T.; Spracklen, W.P.; et al. Shoot yield drives phosphorus use efficiency in Brassica oleracea and correlates with root architecture traits. J. Exp. Bot. 2009, 60, 1953-1968. [CrossRef]

19. Lynch, J.P.; Brown, K.M. Topsoil foraging-An architectural adaptation of plants to low phosphorus availability. Plant Soil 2001, 237, 225-237. [CrossRef]

20. Niu, Y.F.; Chai, R.S.; Jin, G.L.; Wang, H.; Tang, C.X.; Zhang, Y.S. Responses of root architecture development to low phosphorus availability: A review. Ann. Bot. 2013, 112, 391-408. [CrossRef]

21. Fita, A.; Nuez, F.; Picó, B. Diversity in root architecture and response to P deficiency in seedlings of Cucumis melo L. Euphytica 2011, 181, 323-339. [CrossRef]

22. Fan, M.; Zhu, J.; Richards, C.; Brown, K.M.; Lynch, J.P. Physiological roles for aerenchyma in phosphorus-stressed roots. Funct. Plant Biol. 2003, 30, 493-506. [CrossRef]

23. Richardson, A.E.; Lynch, J.P.; Ryan, P.R.; Delhaize, E.; Smith, F.A.; Smith, S.E.; Harvey, P.R.; Ryan, M.H.; Veneklaas, E.J.; Lambers, H.; et al. Plant and microbial strategies to improve the phosphorus efficiency of agriculture. Plant Soil 2011, 349, 121-156. [CrossRef]

24. van de Wiel, C.C.M.; van der Linden, C.G.; Scholten, O.E. Improving phosphorus use efficiency in agriculture: Opportunities for breeding. Euphytica 2016, 207, 1-22. [CrossRef]

25. Bosland, P.W.; Votava, E.J. Peppers: Vegetable and Spice Capsicums; CABI Publishing: Wallingford, Oxon, UK, 2012; ISBN 178064020X.

26. Food and Agriculture Organization of the United Nations. FAOSTAT Statistics Database; FAO: Rome, Italy, 2019.

27. DeWitt, D.; Bosland, P.W. Peppers of the World: An Identification Guide; Ten Speed Press: Berkeley, CA, USA, 1996; ISBN 0898158400.

28. Sahitya, U.L.; Krishna, M.S.R.; Suneetha, P. Integrated approaches to study the drought tolerance mechanism in hot pepper (Capsicum annuum L.). Physiol. Mol. Biol. Plants 2019, 25, 637-647. [CrossRef]

29. Hwang, E.-W.; Kim, K.-A.; Park, S.-C.; Jeong, M.-J.; Byun, M.-O.; Kwon, H.-B. Expression profiles of hot pepper (Capsicum annuum) genes under cold stress conditions. J. Biosci. 2005, 30, 657-667. [CrossRef] [PubMed]

30. Jing, H.; Li, C.; Ma, F.; Ma, J.-H.; Khan, A.; Wang, X.; Zhao, L.-Y.; Gong, Z.-H.; Chen, R.-G. Genome-wide identification, expression diversication of dehydrin gene family and characterization of CaDHN3 in pepper (Capsicum annuum L.). PLoS ONE 2016, 11, e0161073. [CrossRef] [PubMed] 
31. Pereira-Dias, L.; Vilanova, S.; Fita, A.; Prohens, J.; Rodríguez-Burruezo, A. Genetic diversity, population structure, and relationships in a collection of pepper (Capsicum spp.) landraces from the Spanish centre of diversity revealed by genotyping-by-sequencing (GBS). Hortic. Res. 2019, 6, 54. [CrossRef]

32. Fita, A.; Alonso, J.; Martínez, I.; Avilés, J.; Mateu, M.; Rodríguez-Burruezo, A. Evaluating Capsicum spp. root architecture under field conditions. In Proceedings of the Breakthroughs in the Genetics and Breeding of Capsicum and Eggplant; Lanteri, S., Rotino, G.L., Eds.; Università degli Studi di Torino: Torino, Italy, 2013; pp. 373-376.

33. Fita, A.; Picó, B.; Roig, C.; Nuez, F. Performance of Cucumis melo ssp. agrestis as a rootstock for melon. J. Hortic. Sci. Biotechnol. 2007, 82, 184-190. [CrossRef]

34. Ministerio de Agricultura, Pesca y Alimentación. Métodos Oficiales de Análisis; MAPA: Madrid, Spain, 1994.

35. Hills, T.M.L.; Jackson, F. Agricultural Experimentation: Design and Analysis; Wiley: New York, NY, USA, 1978; ISBN 978-0-471-02352-4.

36. R Development Core Team. R: A Language and Environment for Statistical Computing; R Foundation for Statistical Computing: Vienna, Austria, 2009.

37. Wickham, H. ggplot2: Elegant Graphics for Data Analysis; Springer International Publishing: Basel, Switzerland, 2016; ISBN 978-3-319-24277-4.

38. Bouain, N.; Shahzad, Z.; Rouached, A.; Khan, G.A.; Berthomieu, P.; Abdelly, C.; Poirier, Y.; Rouached, H. Phosphate and zinc transport and signalling in plants: Toward a better understanding of their homeostasis interaction. J. Exp. Bot. 2014, 65, 5725-5741. [CrossRef] [PubMed]

39. Ham, B.-K.; Chen, J.; Yan, Y.; Lucas, W.J. Insights into plant phosphate sensing and signaling. Curr. Opin. Biotechnol. 2018, 49, 1-9. [CrossRef] [PubMed]

40. Rose, T.J.; Pariasca-Tanaka, J.; Rose, M.T.; Fukuta, Y.; Wissuwa, M. Genotypic variation in grain phosphorus concentration, and opportunities to improve P-use efficiency in rice. Field Crop. Res. 2010, 119, 154-160. [CrossRef]

41. Bryant, R.J.; Dorsch, J.A.; Peterson, K.L.; Rutger, J.N.; Raboy, V. Phosphorus and mineral concentrations in whole grain and milled low phytic acid (lpa) 1-1 rice. Cereal Chem. 2005, 82, 517-522. [CrossRef]

42. Russo, V.M. Peppers: Botany, Production and Uses; Russo, V.M., Ed.; CABI: Wallingford, UK, 2012; ISBN 9781845937676.

43. Akhtar, M.S.; Oki, Y.; Adachi, T. Genetic variability in phosphorus acquisition and utilization efficiency from sparingly soluble P-sources by Brassica cultivars under P-stress environment. J. Agron. Crop Sci. 2008, 194, 380-392. [CrossRef]

44. Hu, Y.; Ye, X.; Shi, L.; Duan, H.; Xu, F. Genotypic differences in root morphology and phosphorus uptake kinetics in Brassica napus under low phosphorus supply. J. Plant Nutr. 2010, 33, 889-901. [CrossRef]

45. Bates, T.R.; Lynch, J.P. Root hairs confer a competitive advantage under low phosphorus availability. Plant Soil 2001, 236, 243-250. [CrossRef]

46. Strock, C.F.; Morrow de la Riva, L.; Lynch, J.P. Reduction in root secondary growth as a strategy for phosphorus acquisition. Plant Physiol. 2018, 176, 691-703. [CrossRef] [PubMed]

47. López-Bucio, J.; Cruz-Ramírez, A.; Herrera-Estrella, L. The role of nutrient availability in regulating root architecture. Curr. Opin. Plant Biol. 2003, 6, 280-287. [CrossRef]

48. Miguel, M.A.; Postma, J.A.; Lynch, J.P. Phene synergism between root hair length and basal root growth angle for phosphorus acquisition. Plant Physiol. 2015, 167, 1430-1439. [CrossRef]

(C) 2020 by the authors. Licensee MDPI, Basel, Switzerland. This article is an open access article distributed under the terms and conditions of the Creative Commons Attribution (CC BY) license (http://creativecommons.org/licenses/by/4.0/). 